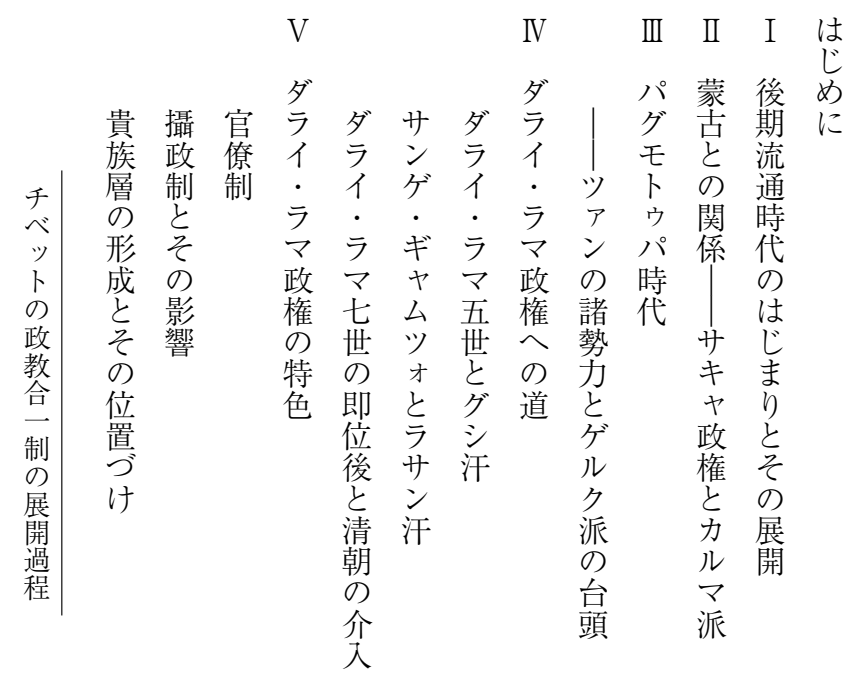

チ

ベ

ツ

卜

の)

政

教

合

制

の

展

開

ミ゙ラマた名権 世

- 一た と確に教

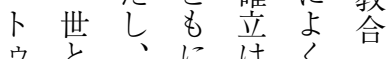

パ 称宗合そ知 の

○教わ机ら組

二 れ界せ程れ織

三るにも古て織

九よ拈つくい頂

二ウけたなる な点

四な存 七五ダうと

四さ在五名 らでて

九、し年イあの

ツて以・る名

をオは来ラがラ

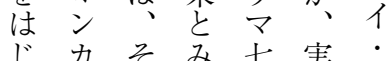

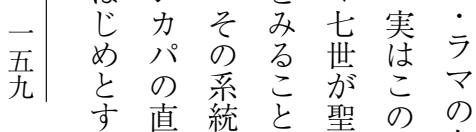

参お
考 わ
文り

過

る弟は古俗名存

が子後で両ラ在

当一多るき界イは

ば 献に

程

め

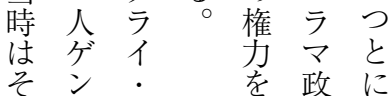

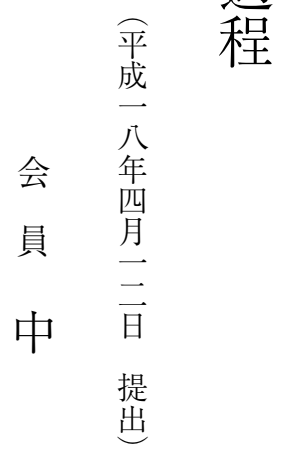

根

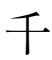

枝 

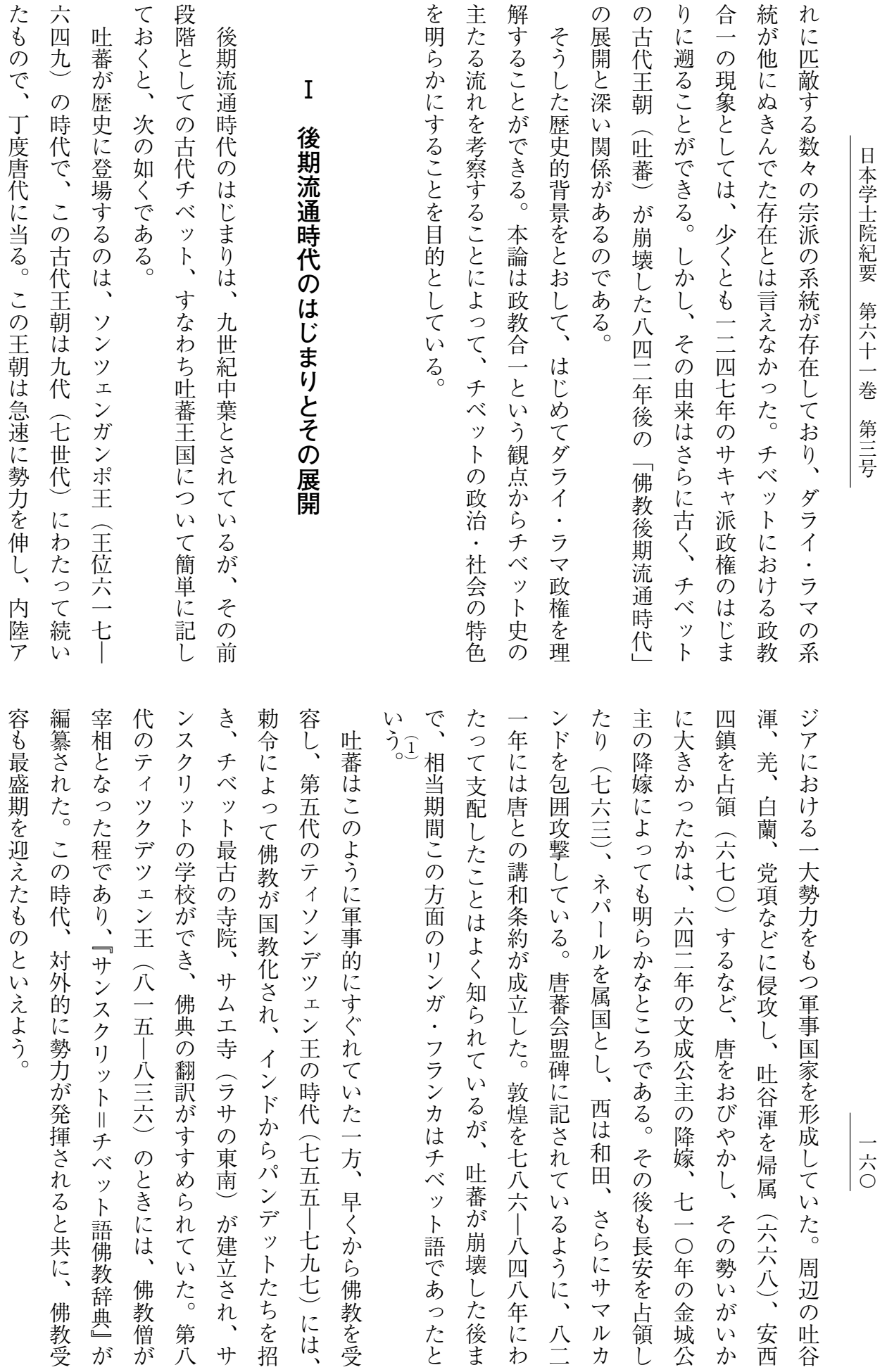

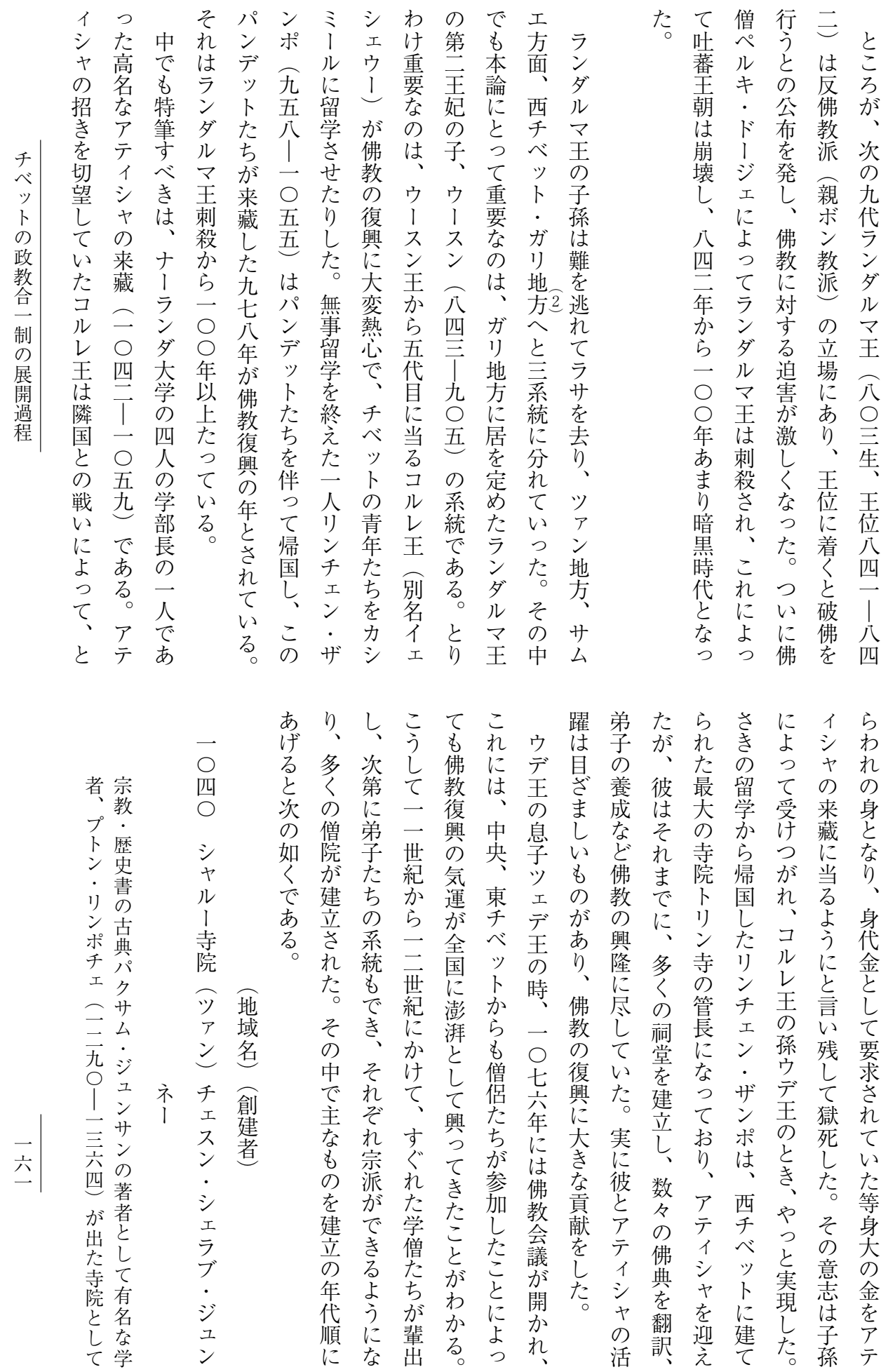

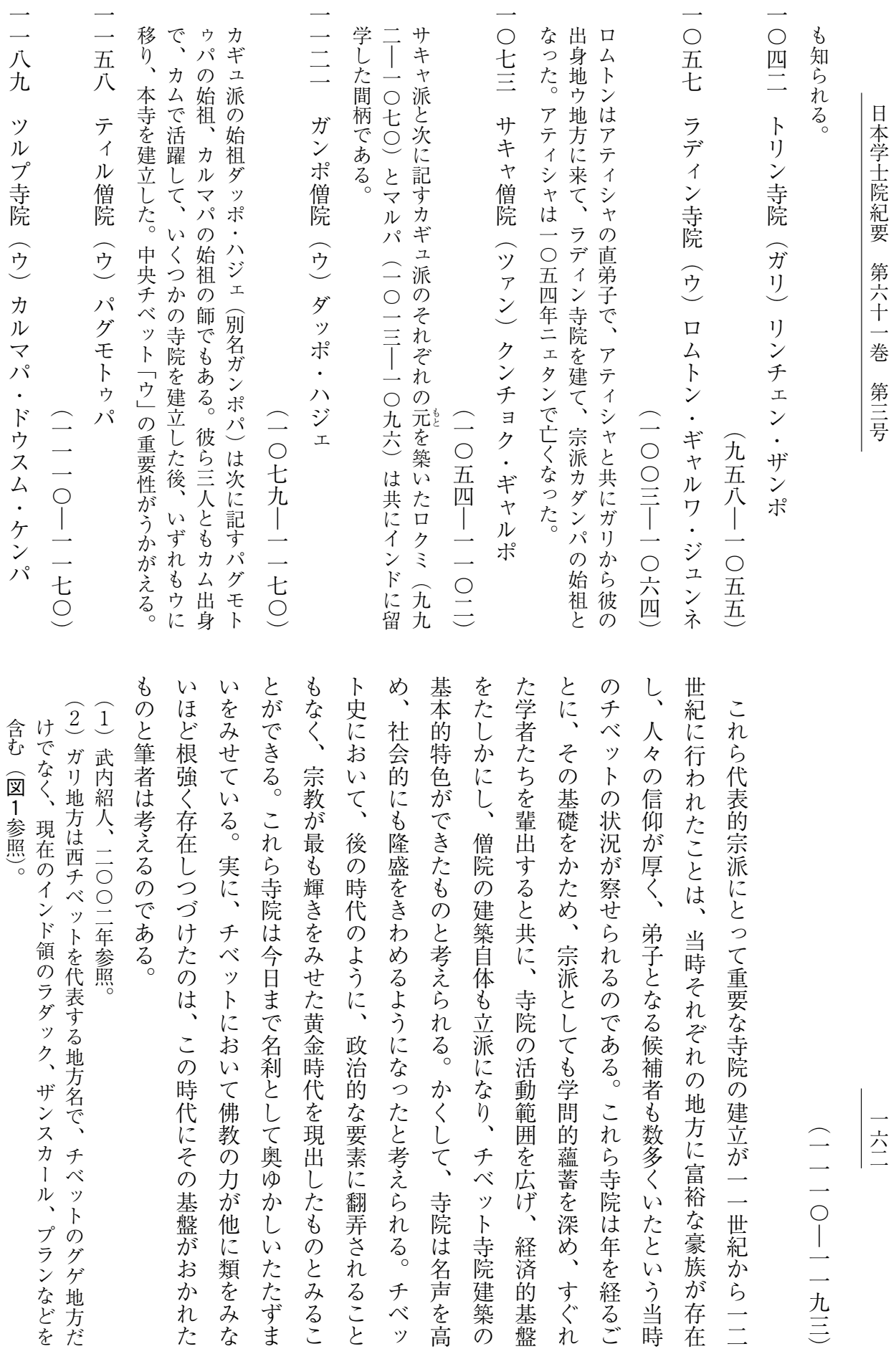


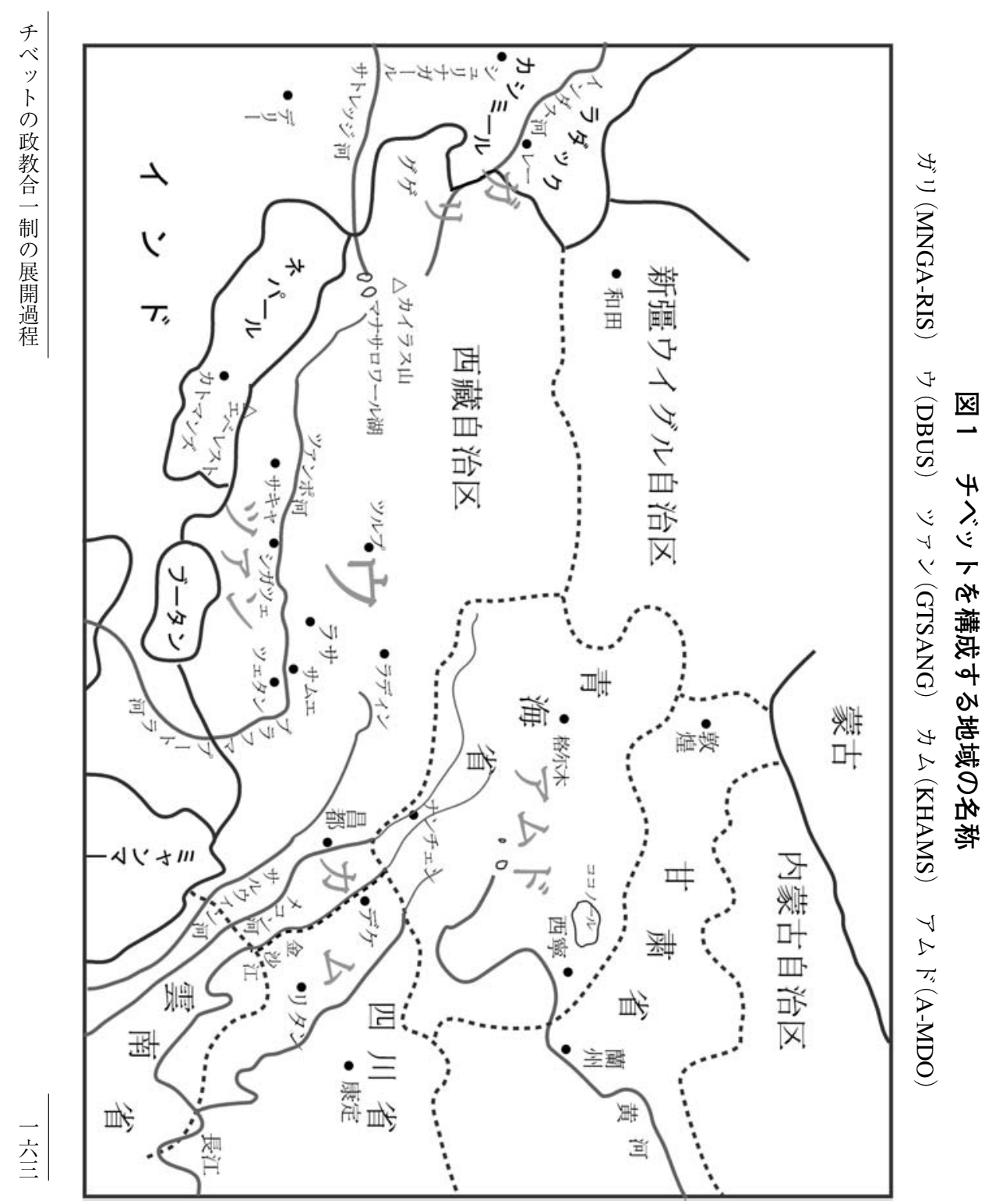




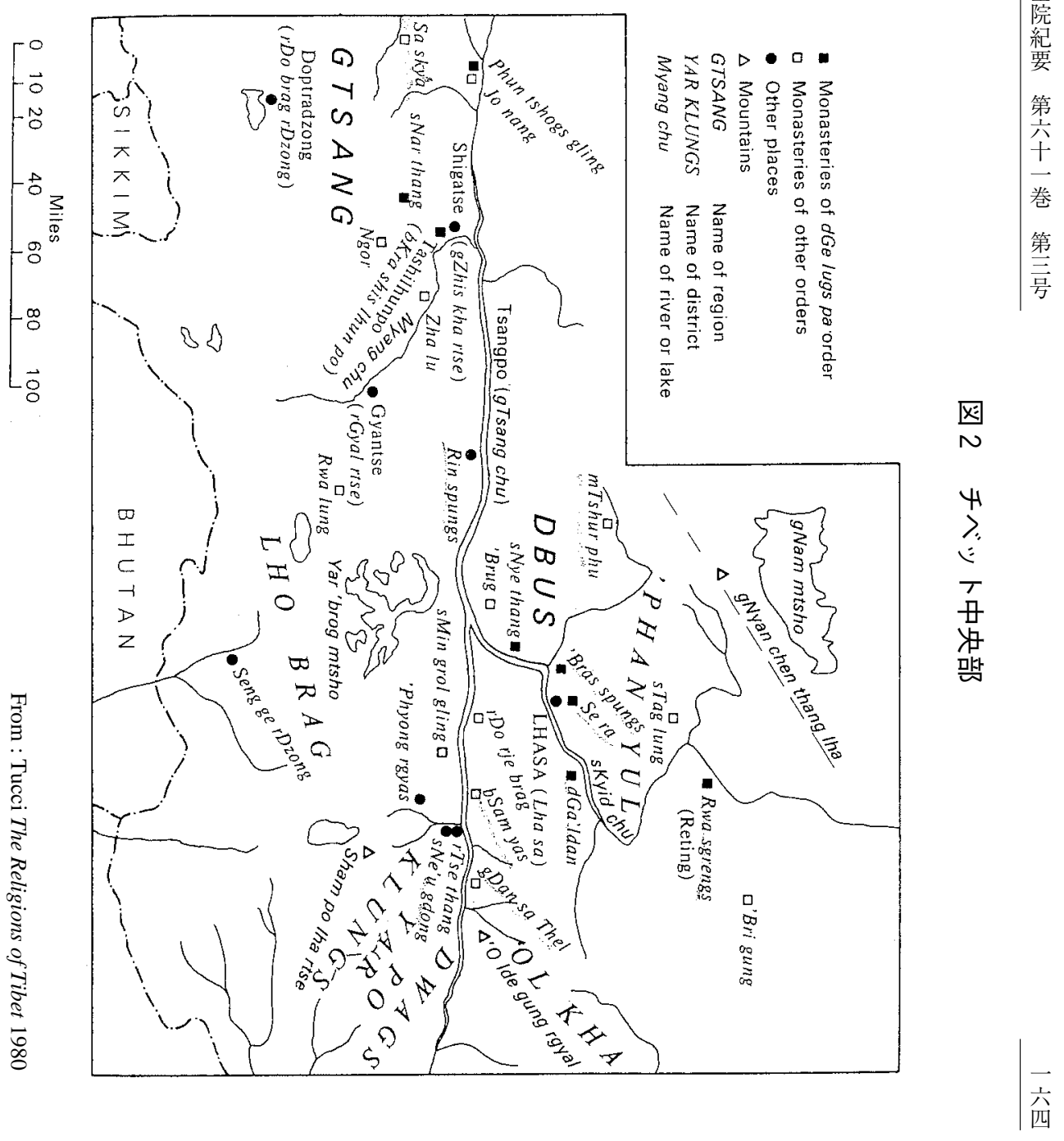




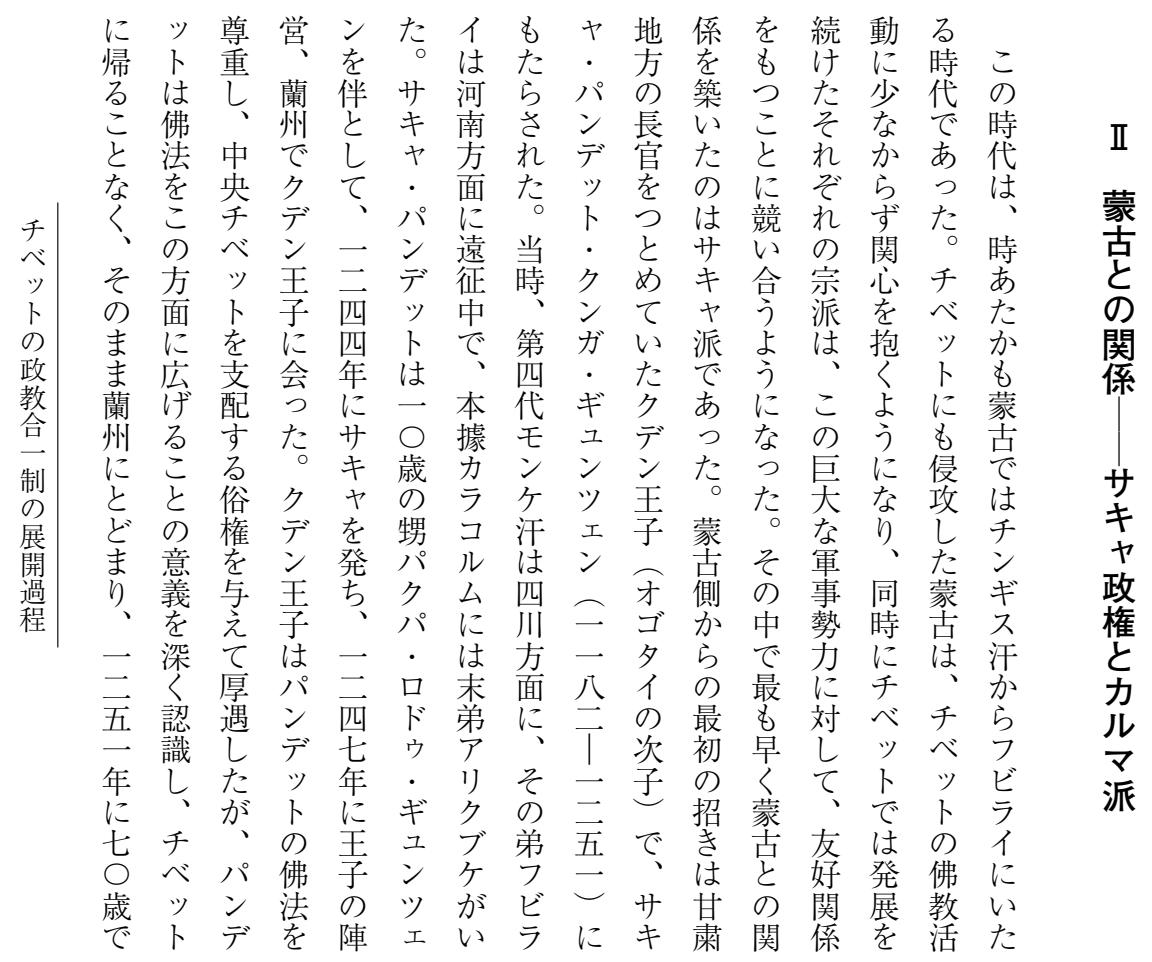

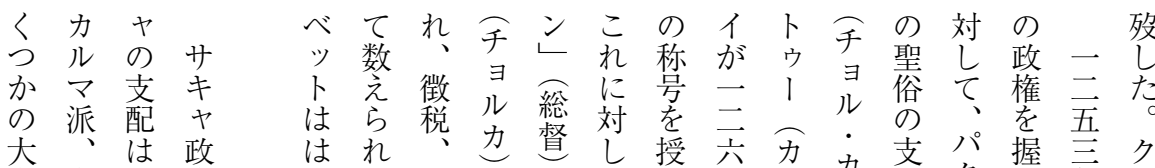

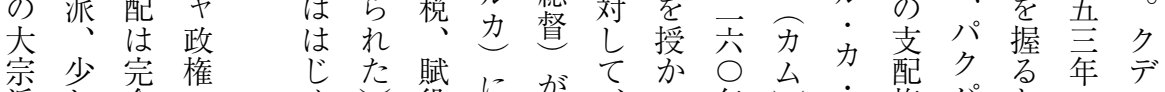

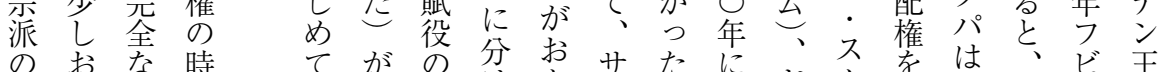

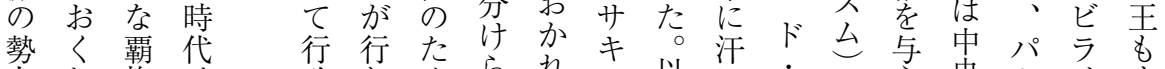

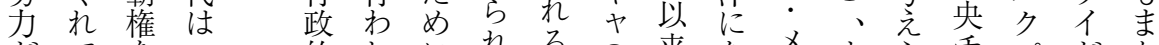
がてを—的れに机るの来なメすすら千パがた

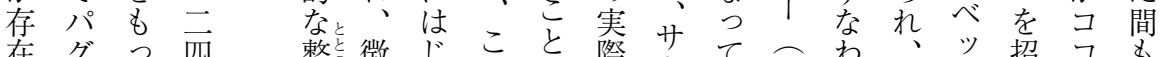

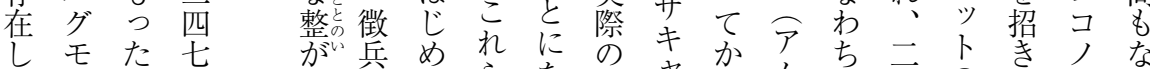
だ た

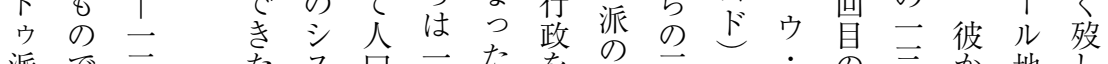

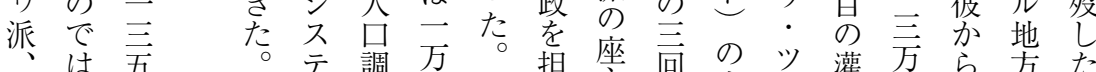

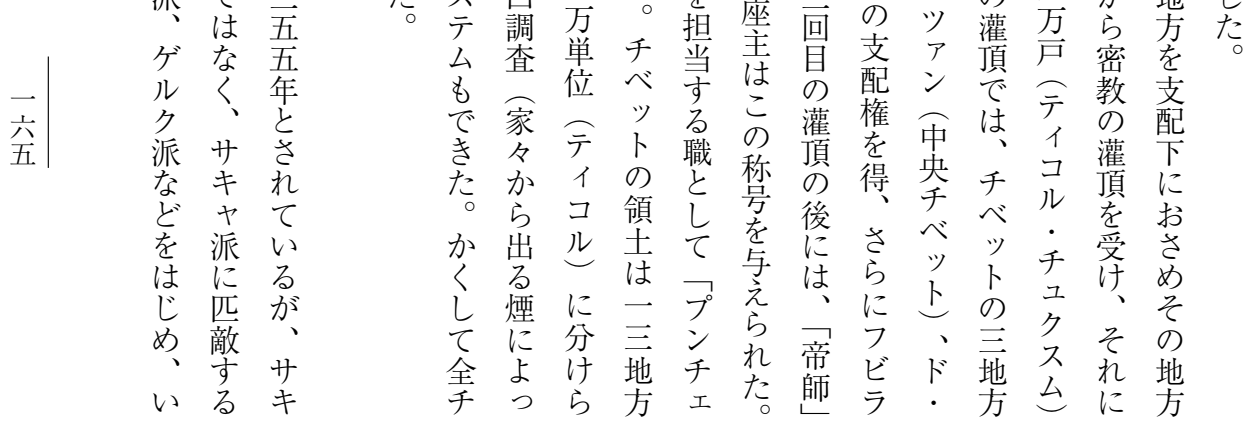




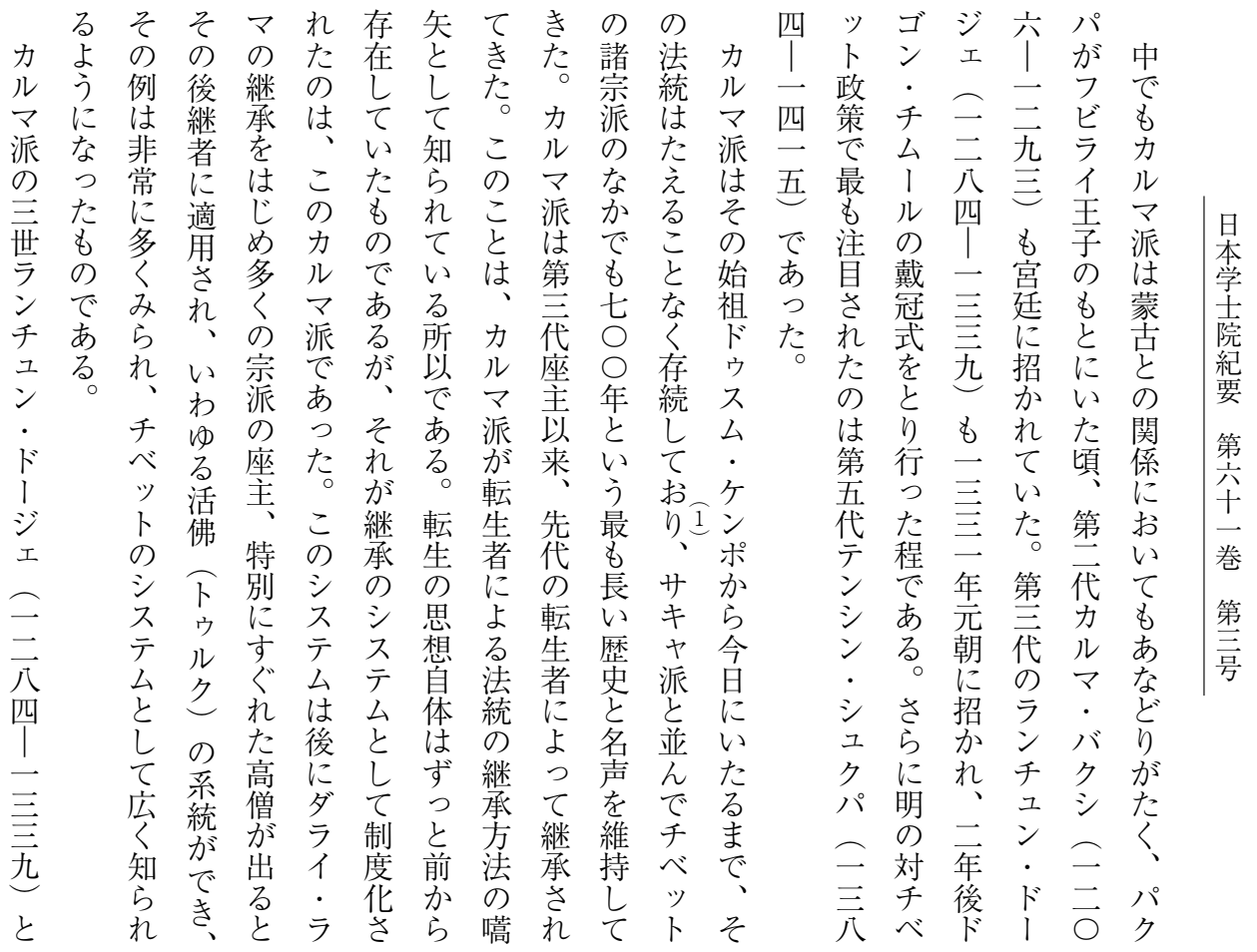

の許族でシ一

者さの学族力

を老中つテのル

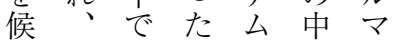

補甥座り、がで派

者継主、承 内座 の

す 加座紛れ 生

るらを老て帝 の

う長め男ぐり た

に継つ、。の

な承てコし継么

た事簿 ンか承に

実的 が、行 し

こ上な四パわ样方

た諸相のパたサ

め系も系のたキ

候統あ統死めヤ

補全らに凍わ分派

自のれ歴父場

身中、た代「合

ので後り座甥は

能最妻て 主 の゙継コ

資長帝 一短承シ
出 年 現 黑 正敗 ク力在 派 称 ら

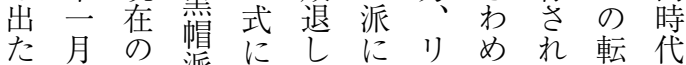
とに座派はこ対ンてるる生に こイ 主は九公抗プ政系者高 でド第ず世でたたン、治統に僧 あ・—と絶元りデ関でつク

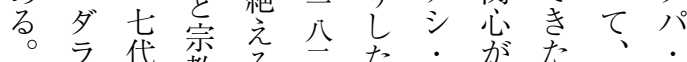
厶ウ教る貣た高強。新セ

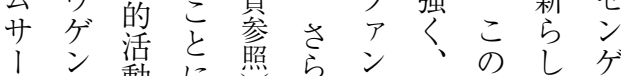
ラ・動に照らにパ後シなっ

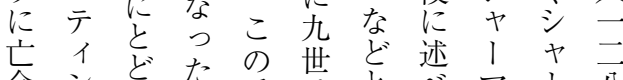
命ン どた

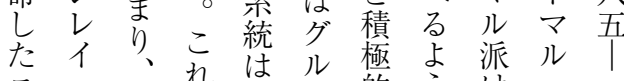

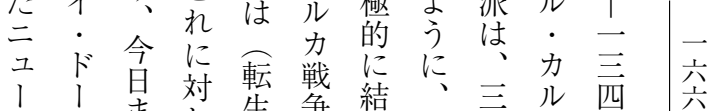
ス はエで存力は者原活令四派が

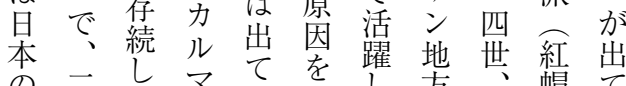
の 章 て

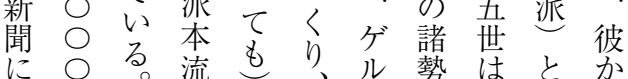




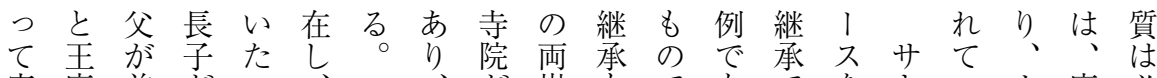
実座前がっ、三、势岸もであでを者キい方座必

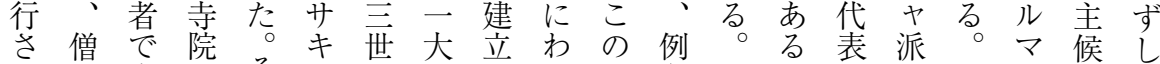
れ俗息のそヤ紀勢さた部えチ。寻のの派補も

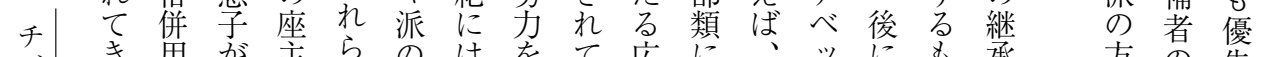

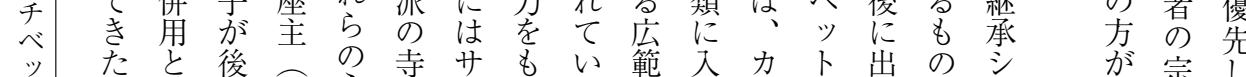

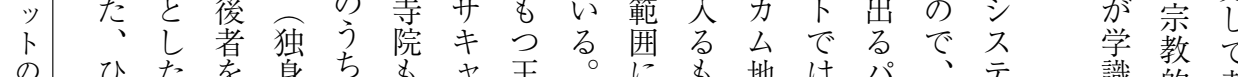

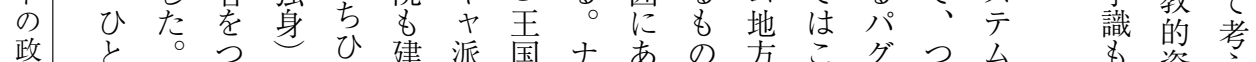

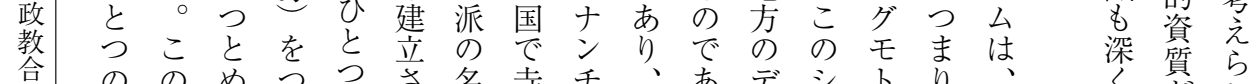
制典よ

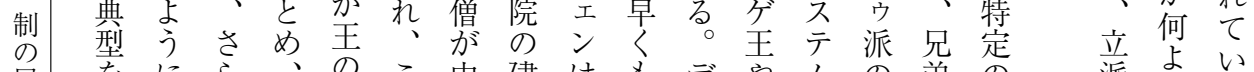

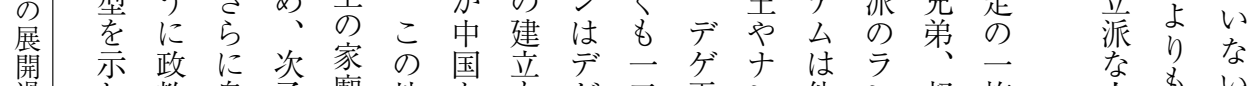

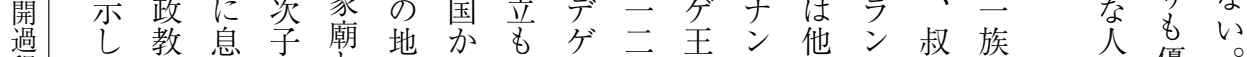

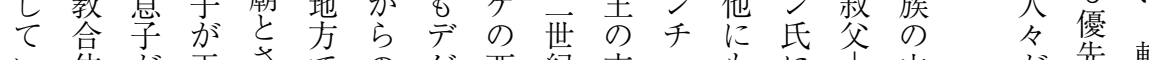
い体が王さでのゲ西紀支エもに俄先転 る制一の势帰と方初配之少占甥吕出さ生

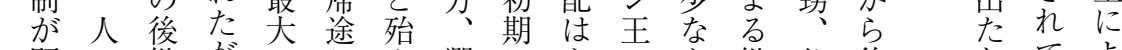
顕の継がのこん闌にかのか継父後とてょ 在場者之勢れど滄はつ家ら承!継いいる 的合市务ら同江力て廟ずは息箸方るシ

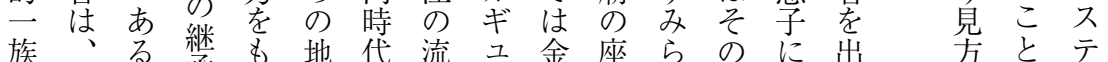

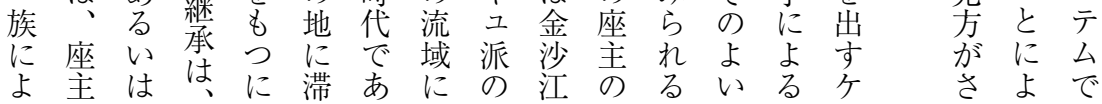

交
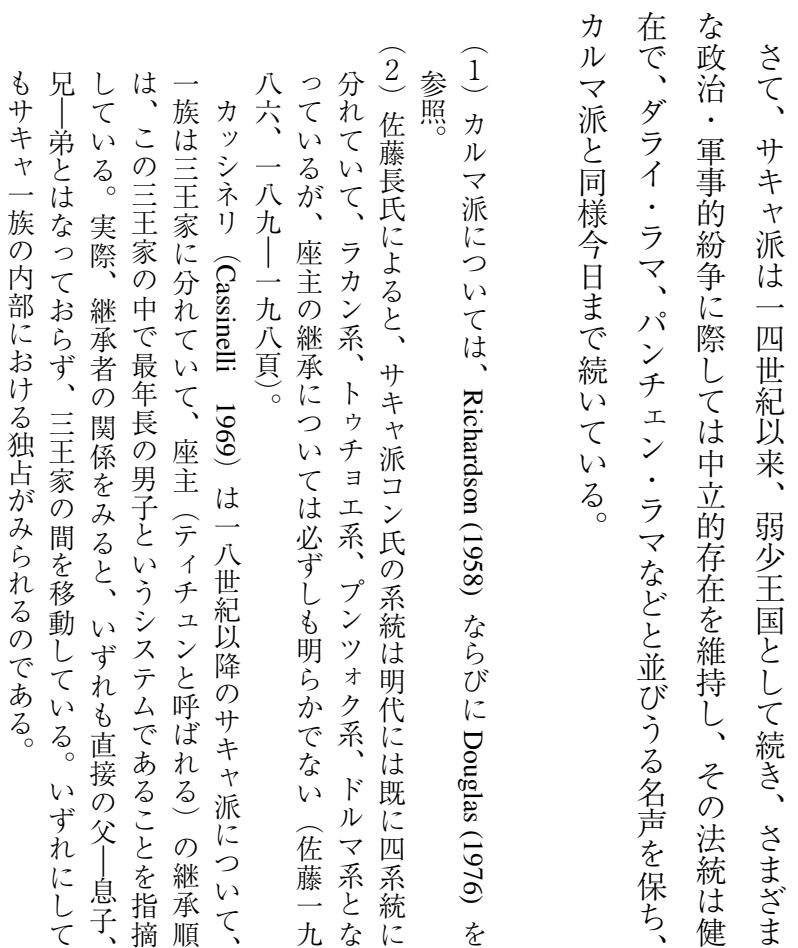


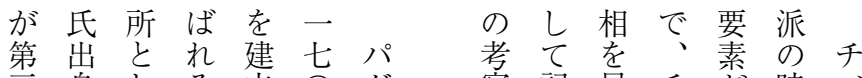

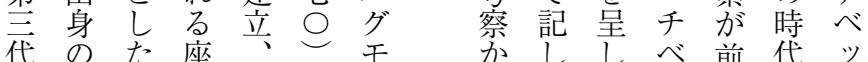

帒のた座多 が主こ でト

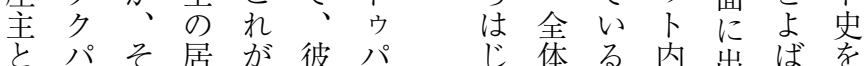

な・の所デはのの的の部て出

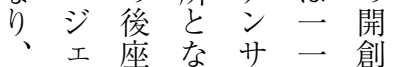

チン主つテ五者

エネのた赤は

ガ在座 第 と 年 カ

. 位し第し出

リ二ば代てをを身

ン三らの同出の

ポ チ究座派て パ

チ八空主 の

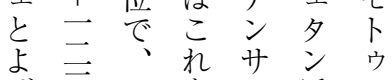

ば吾二立岳近パ

五五 大 千

僵一八築 ン

俗 歳 年 し $\begin{aligned} & \text { ガ } \\ & \text { ル }\end{aligned}$

尊攻 シ 学 と 僧 よ

る 流本 のくる。代

れ論抗る 争方的

展はと文キ移

望々蒙に ヤ に

る 詳諸な権 う

とな細 部、来

に歴の関四千キ

る的係世站ヤ

ま移艻紀

すをりら史の

、き乱一は次

パわれ八次は

グめ、世第 パ

モて複紀にグ

卜簡 杂隹 初 政 モ

ウヘ略な頭治卜

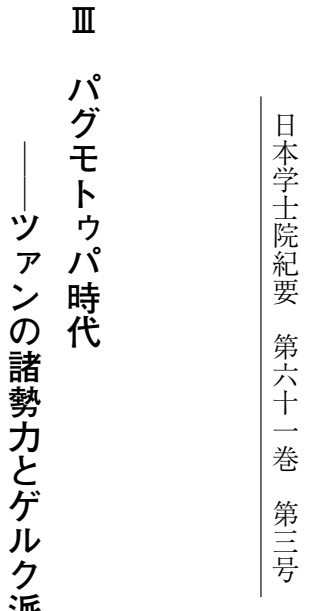

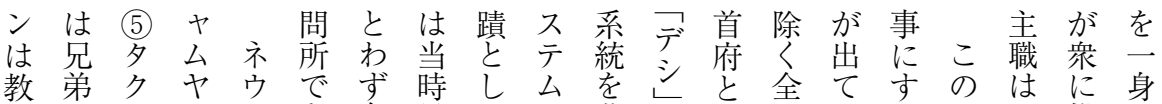
王関パンドあ多最てで輩とし手くぐララ推に 係・゙・ンつく大注あ出称てべ衰れンジさ集

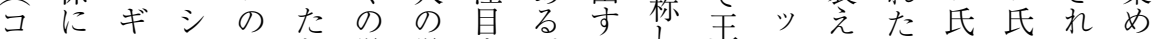

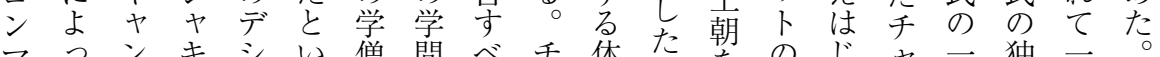
マつンキシい僧問べチ体た䓮のじャ二独二。

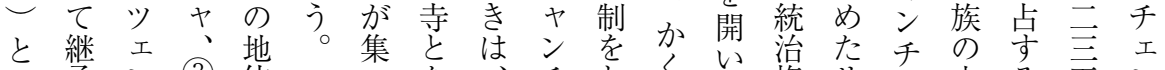

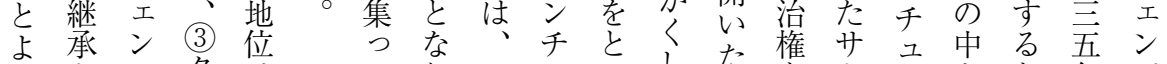

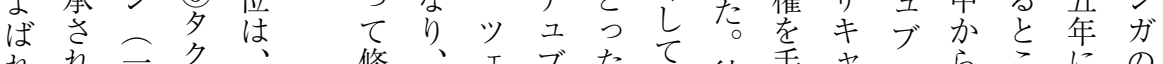
れれ二ク、修、エブたて、彼手ヤ、らこにの

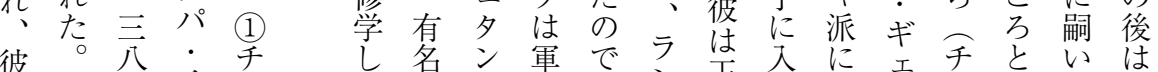

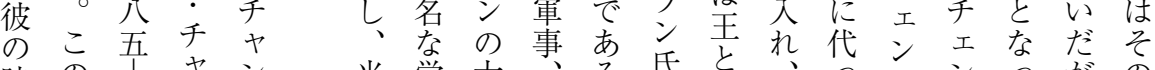

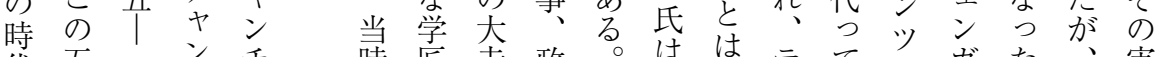

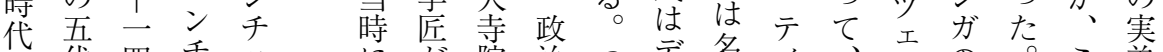
は代四チュに沓院治つデ名イ、エのの弟

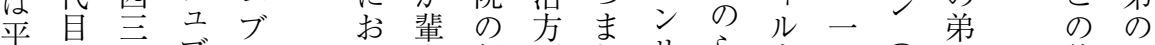

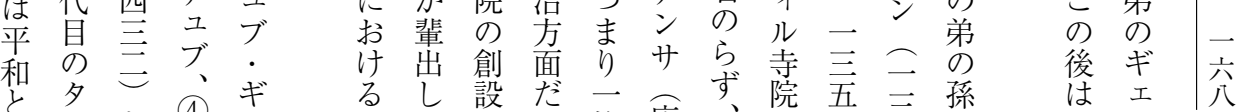

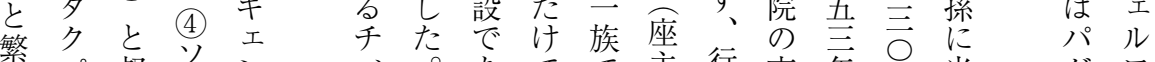

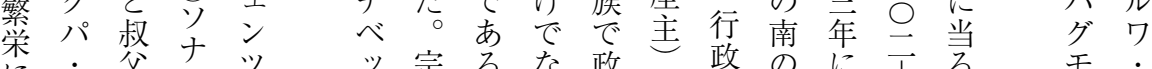

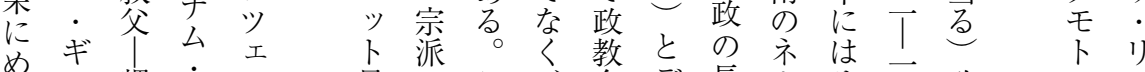

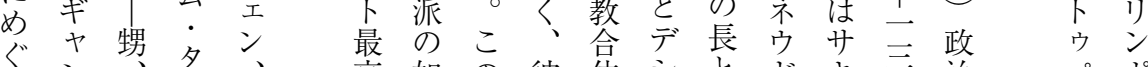
まンン高如の彼体シと流交治パポ

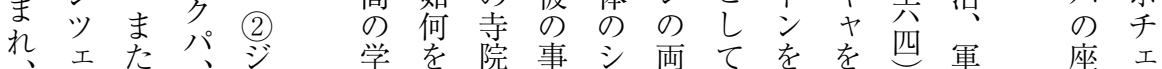


\begin{tabular}{c|} 
チ \\
ベ \\
ト \\
の \\
政 \\
教 \\
合 \\
\hline 制 \\
の \\
展 \\
開 \\
過 \\
程
\end{tabular}

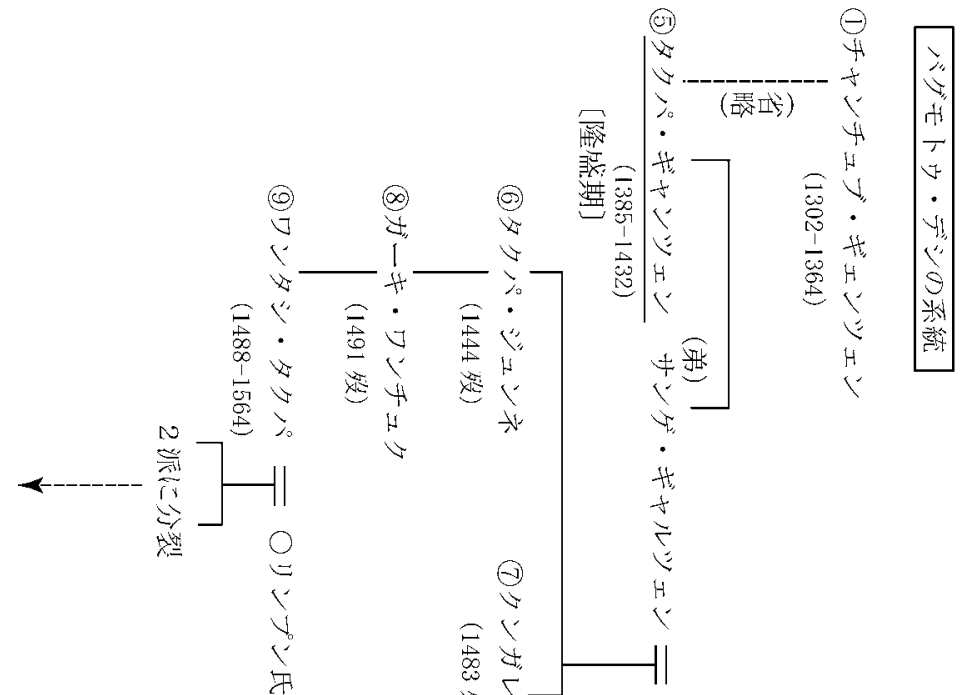

同

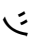

$y$

I

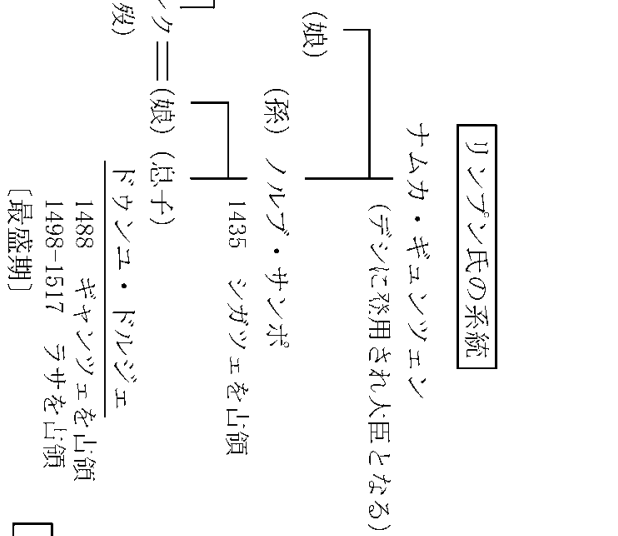

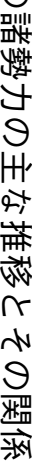




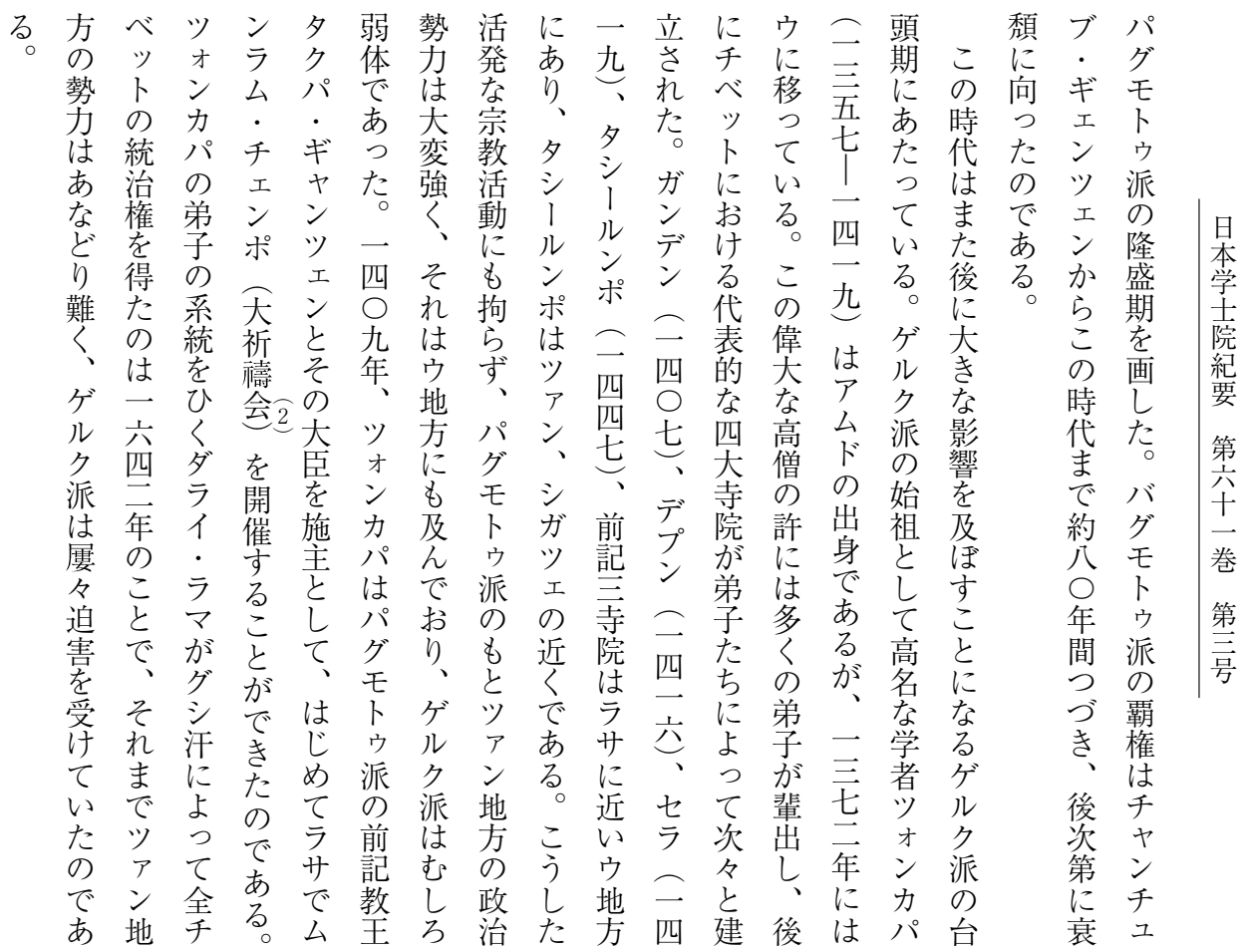

か六デデラ侽ン四た助ンツめ四そらュ 歴 以帒 代後も両二ン八二年ゲ、ド地そ年ノまエマ

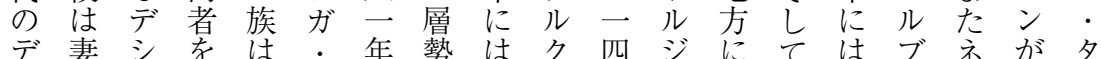

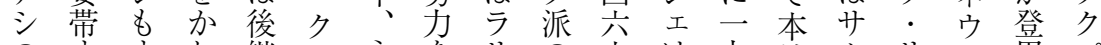

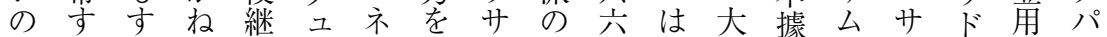

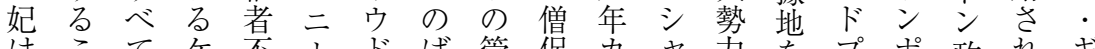
はこてケ不、ドば管侶力ヤ方をプポ政れギ 殆と独 1 足パンし轄たルママを、ツも府、ヤ

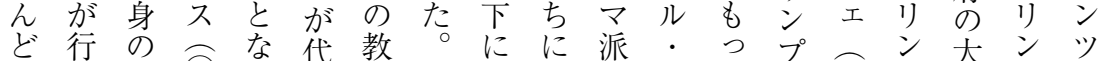

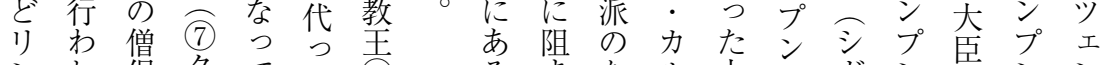
ンれ侶クててて 7 る

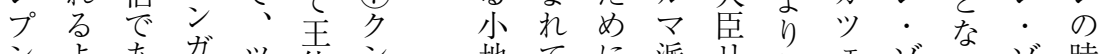

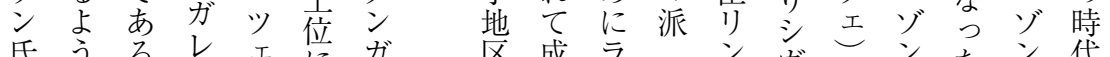
氐に主に

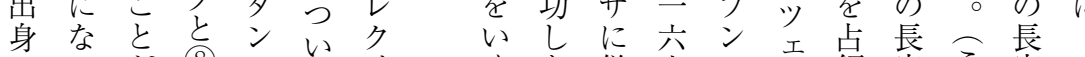

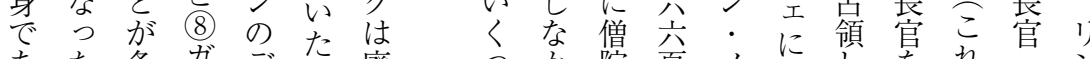

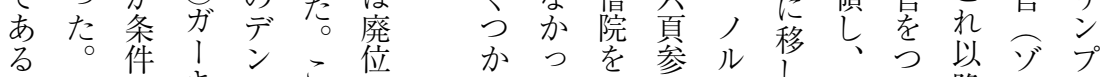

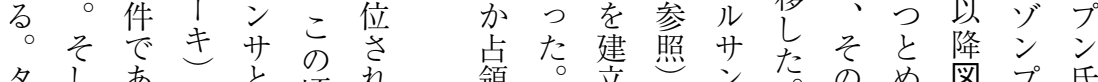

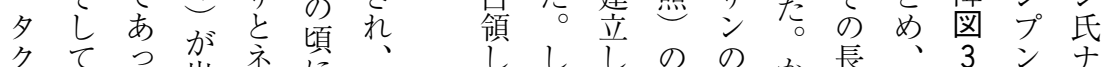

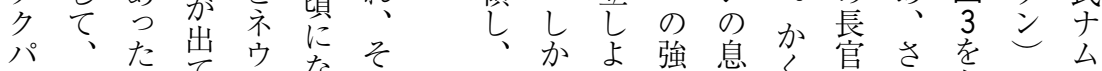

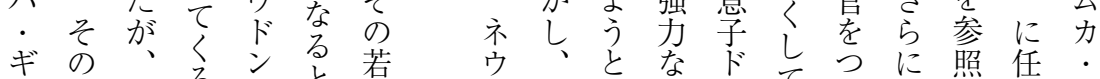

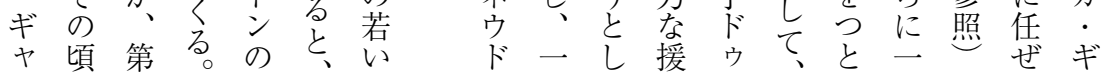




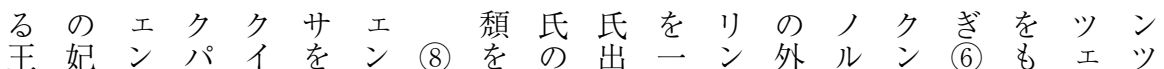
朝にガこシつガ代二勢身層プ戚サガ代つン ン

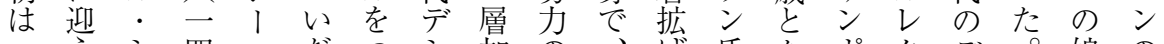

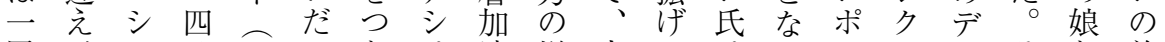

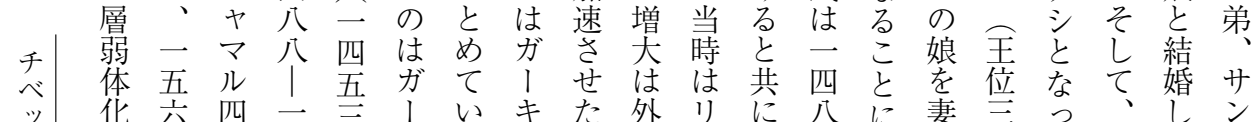
卜 尣世五百 政 グ 年 が 六 助

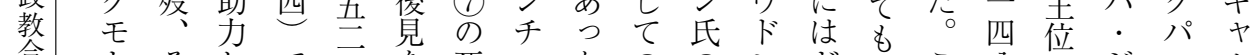
合卜そしで四を死亡たのの゙ンギ勢こ公立ジ・ル

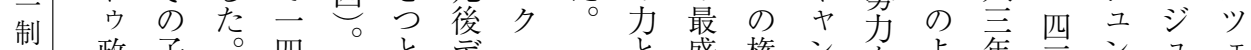

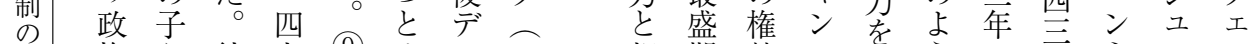

展 権ら彼九 9

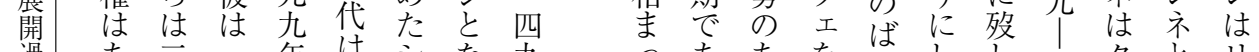

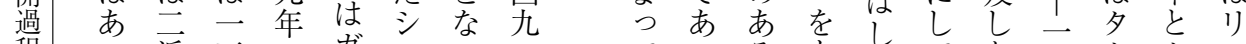

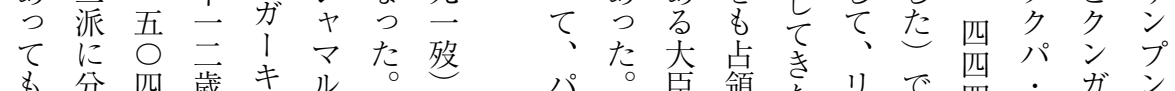
も分四歳キルパ。臣領たりで四・音ン

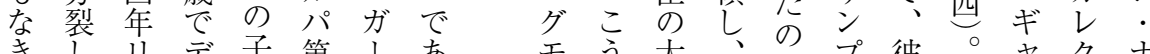

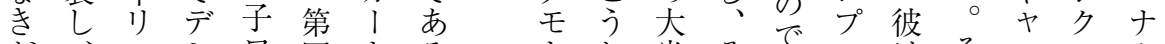
が、シ シ ワ 四キ る

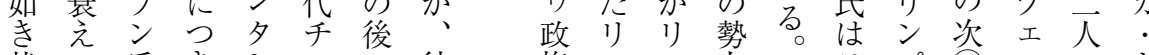

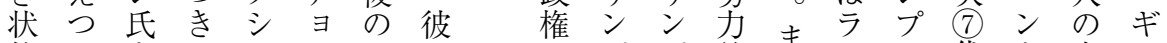
態つをを、・ エデは のププ範またジン代を息ュ

特ナシツしたす合に設は争パ 別么・オたのるにラざな解グ宗年・・、破な な・夕ンよとデ、ンたか決モ教政 ラ一元て

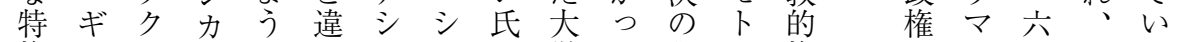
権ヤパパにつ・ヤの学た調ウ権はに四一っ

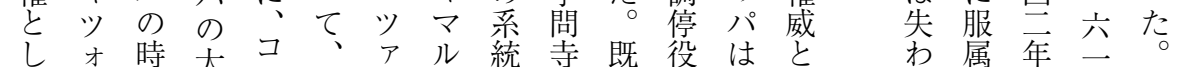

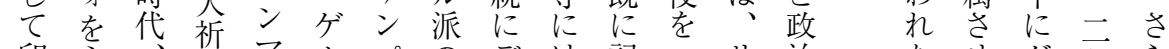

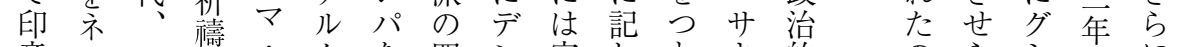

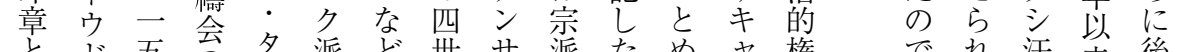
とド五云夕派ど世开派ためせ権だれ汗来後

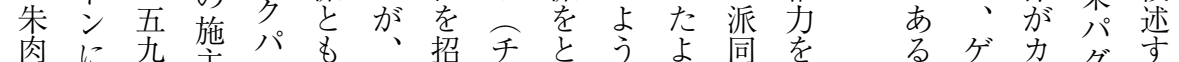

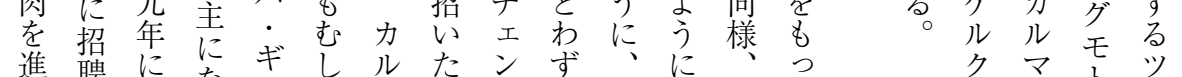
進聘に た 、後 つ

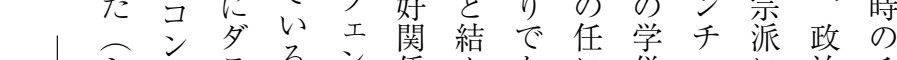

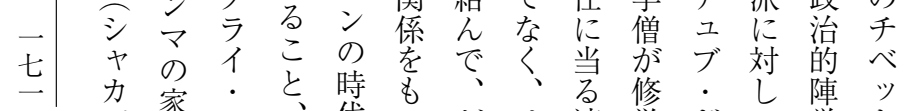

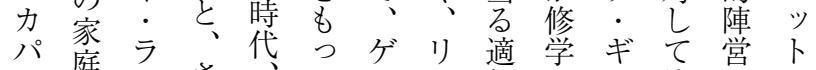
一教夛さ 一 てルン任して決にに

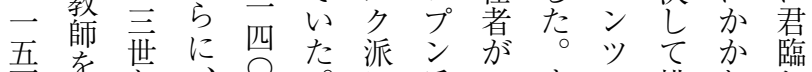

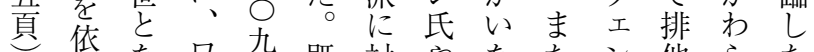
ほ頼なるワ年既詨やなた 後いた他ら た 支配キは パ に 入を支 だ り破配 シ

つた囲ツ いたをア にめ大ン 一、巾パ $\begin{array}{ll}\text { 六夕゙に } & \text { 六 } \\ \text { 失 }\end{array}$ 


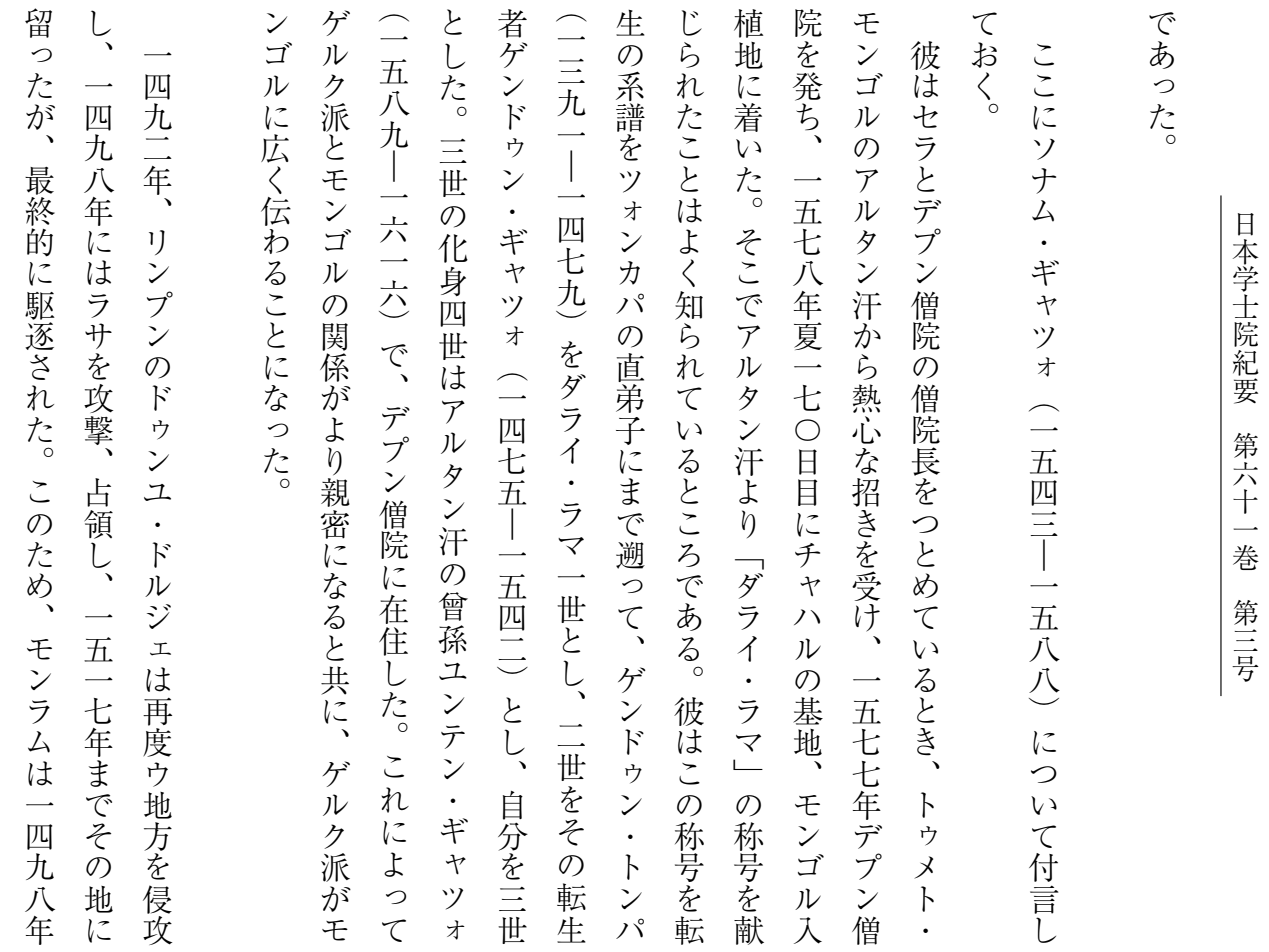

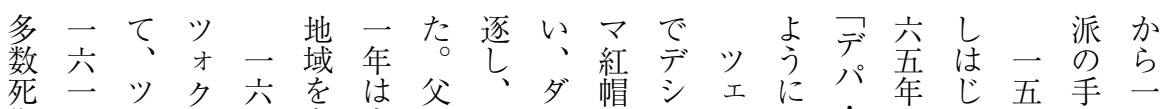

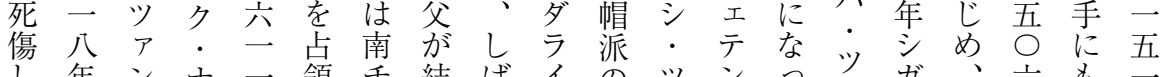

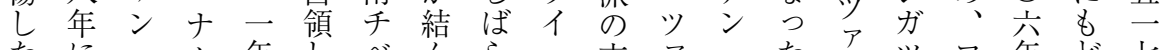

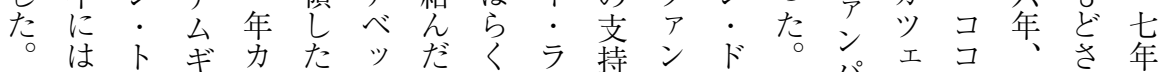

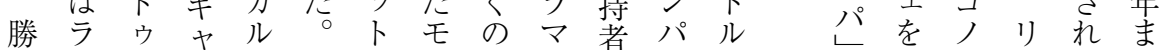

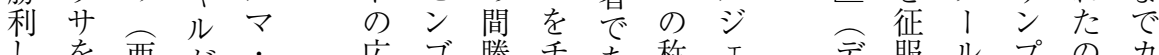
しを西が: 広ゴ勝チ市称エ 站服ルプのカ

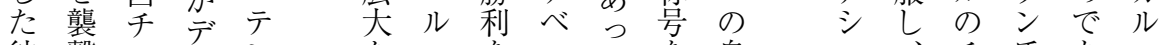

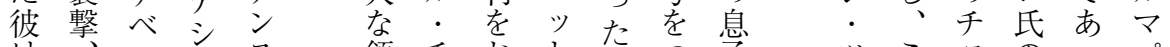

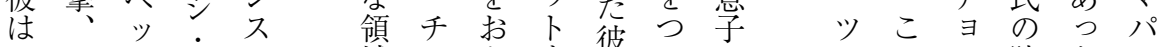

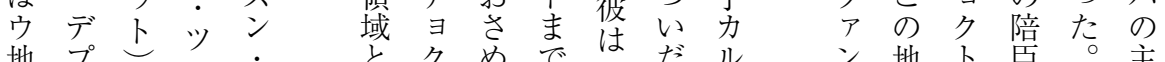
地プ

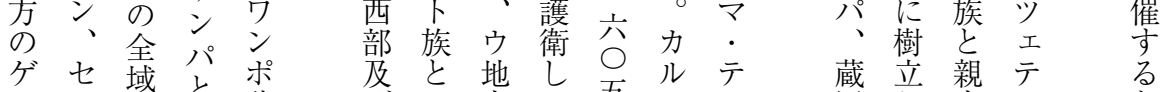

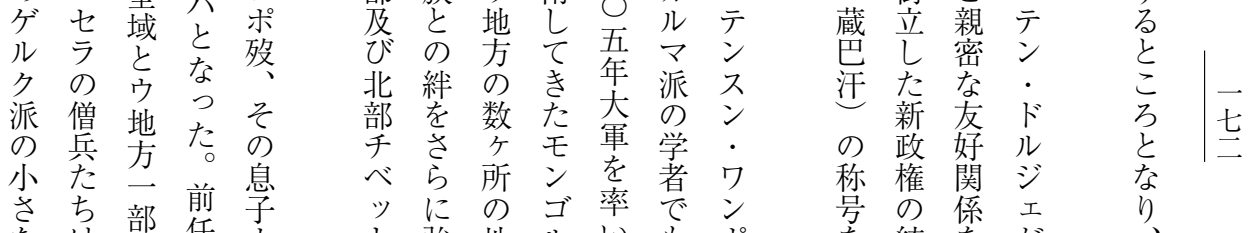

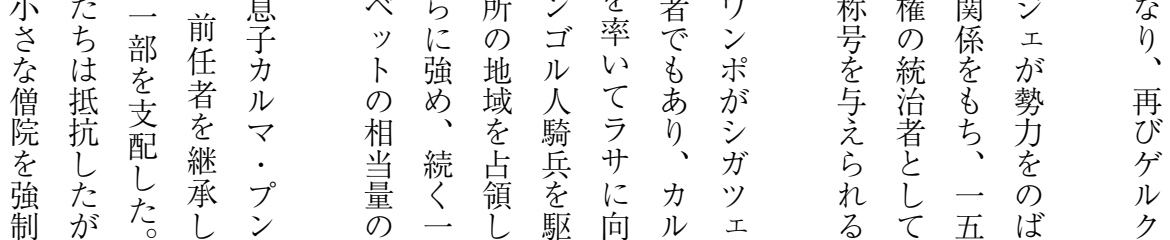




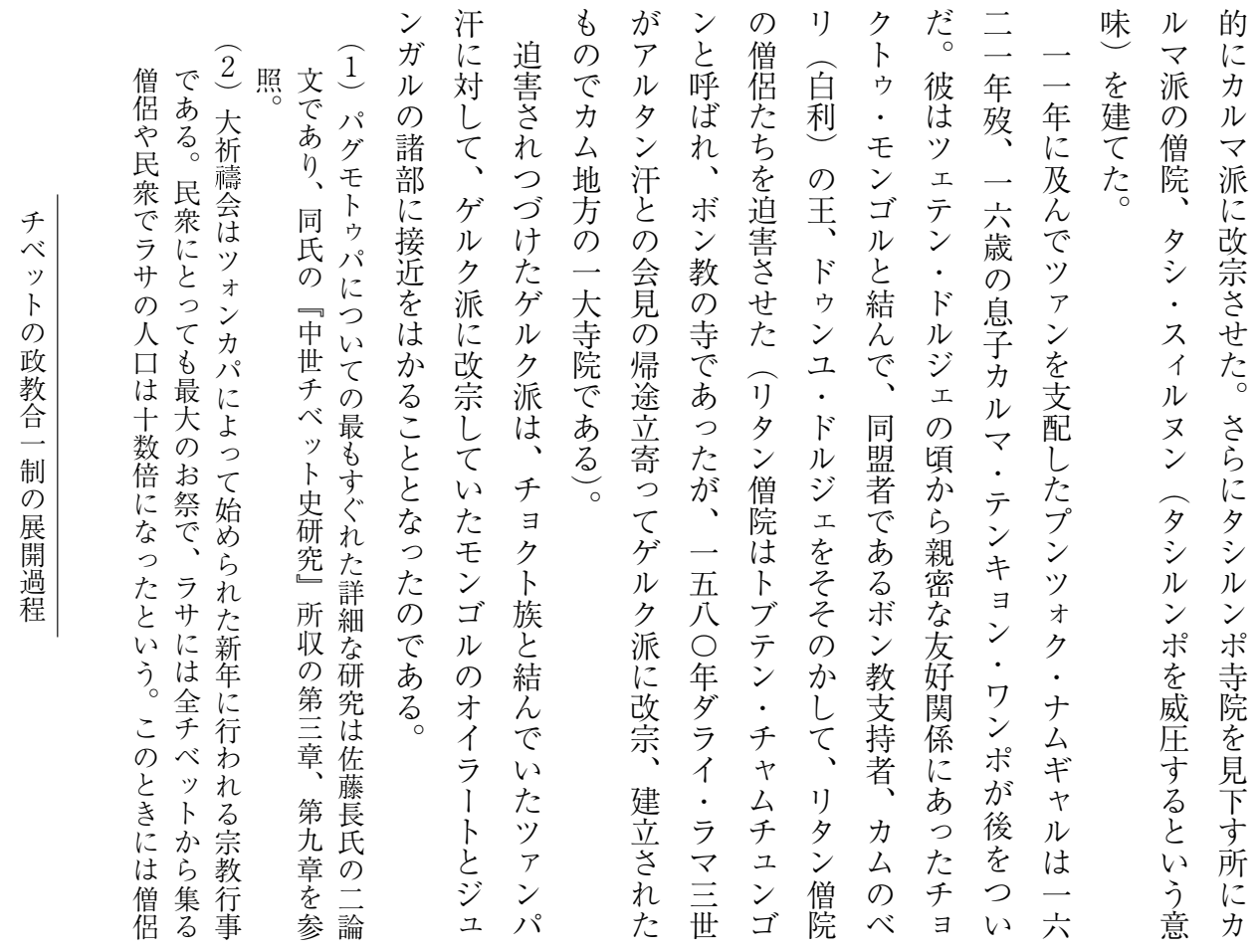

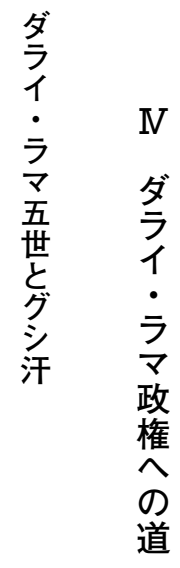

学はとた 位二もにに 取五、よ 得九学る の年僧 有 試二と名 験再しな 受手の并 げ高的 たッ位議 トの論 暦試 新験 年它苚 行 号 にわさ ゲた シ。夕 工現 ク ・多千 八ラヤ ラ シラ行 パマわ 最四る 高世と 


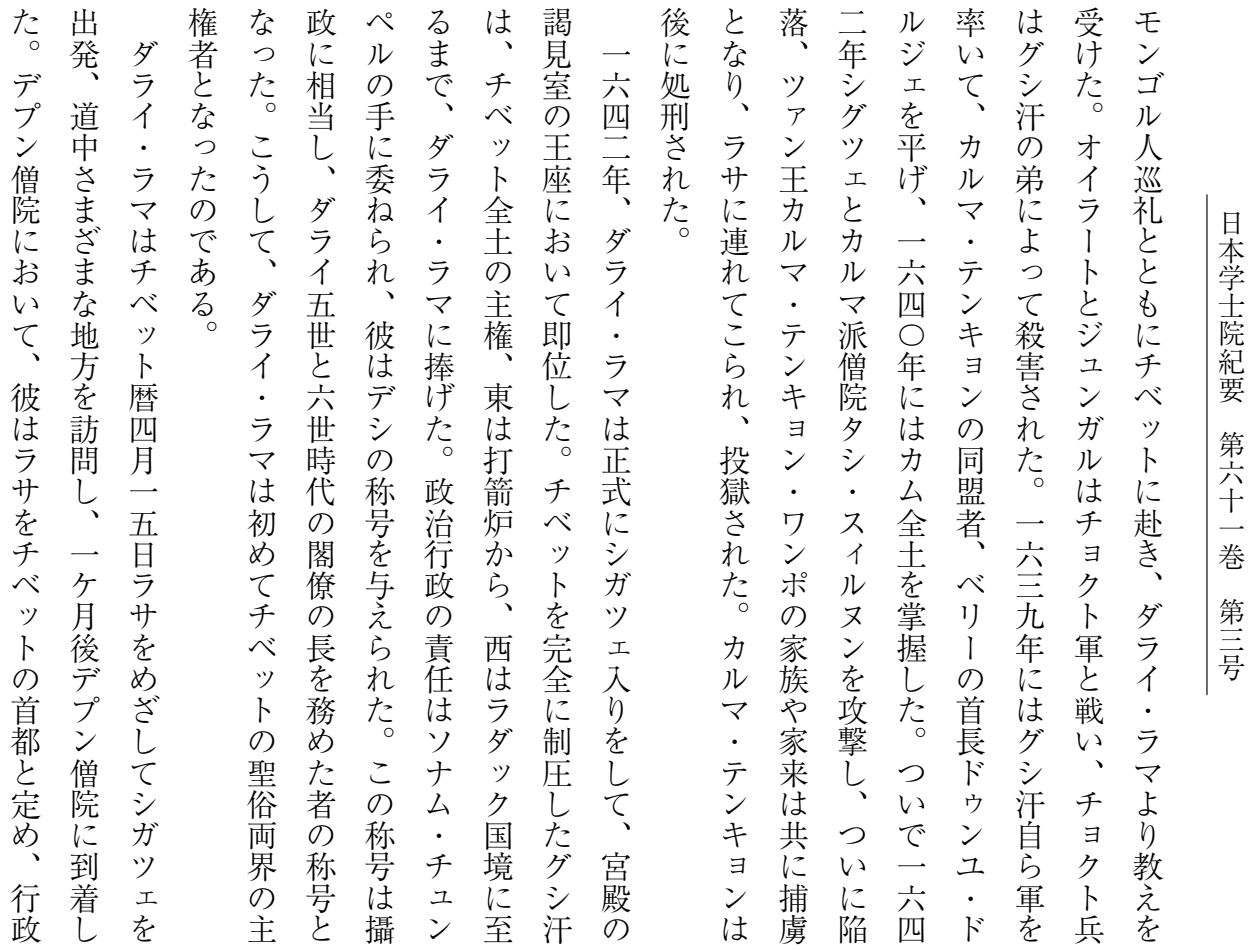

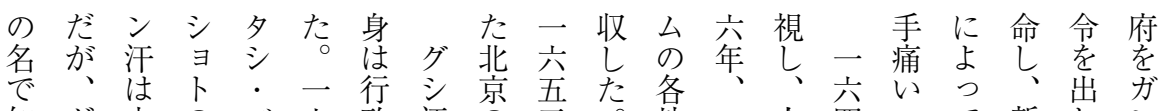

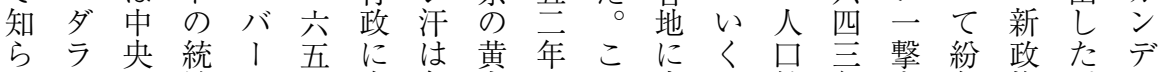
れイ千治卜五介冬寺方の官う統年を撃争権。 る

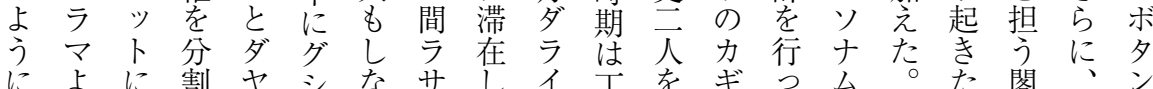

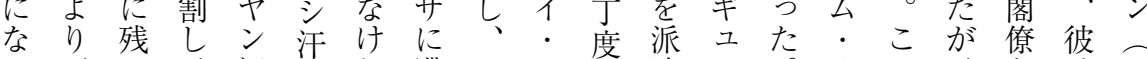
つダつ 、汗㤎れ滞 一 だた タ と 亡 ば 在六、 か

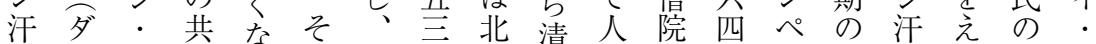

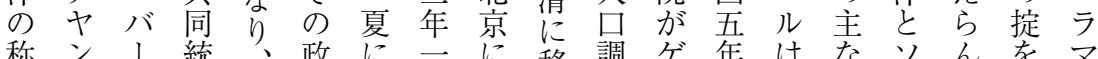

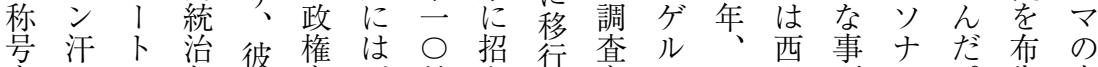

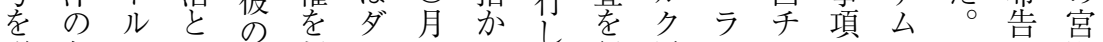

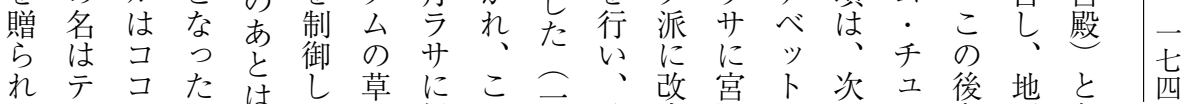

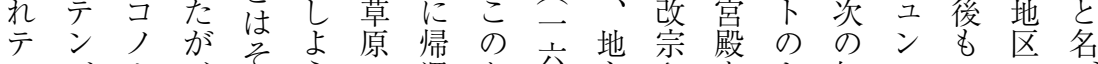
ンジリ、そうで還た尣主ささをト如ぺツののづ ジンルー二 一過しめ四方着ウくルア行け ン・地六人方六の し た に ダル

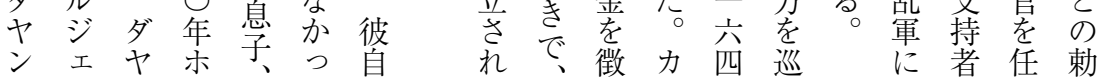




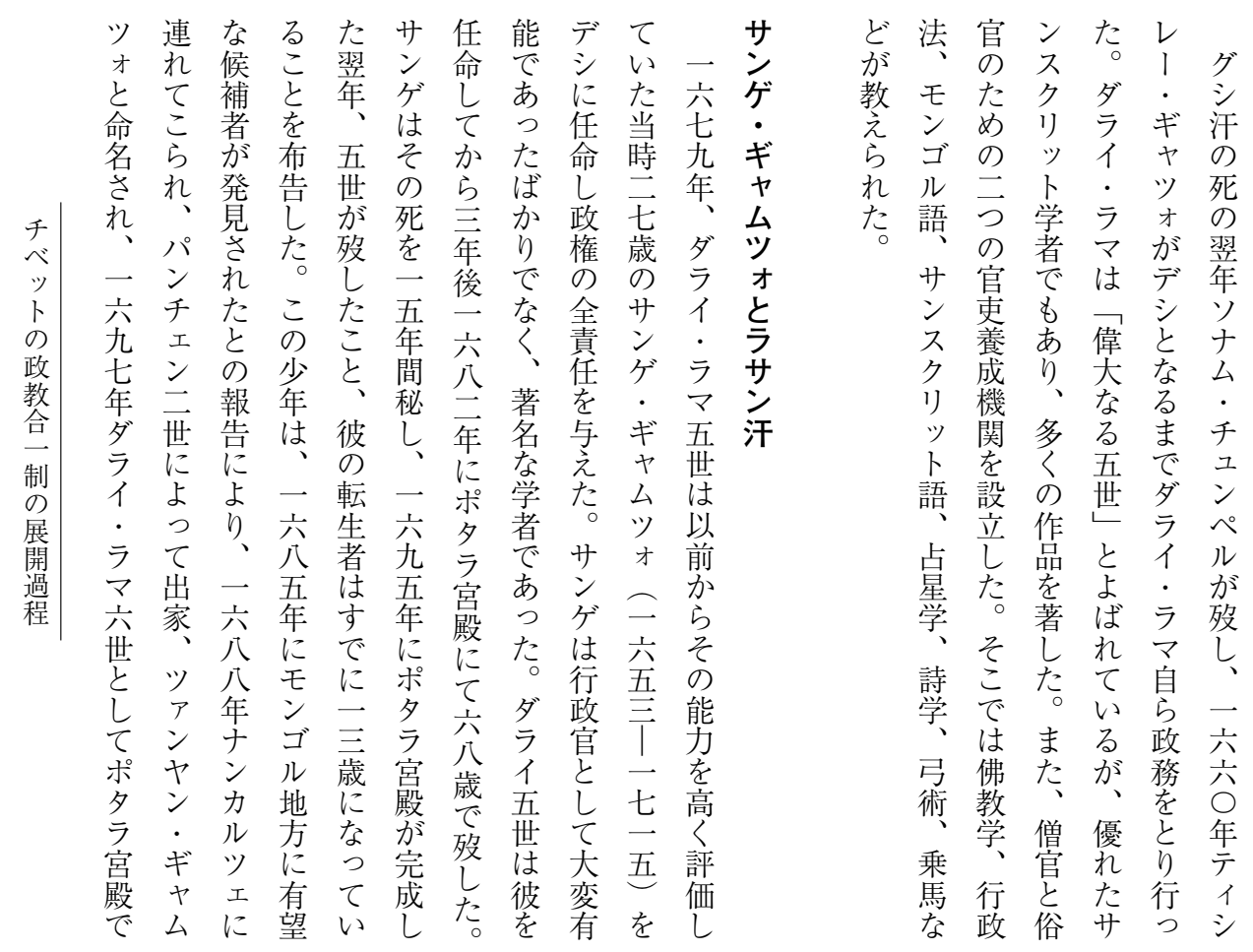

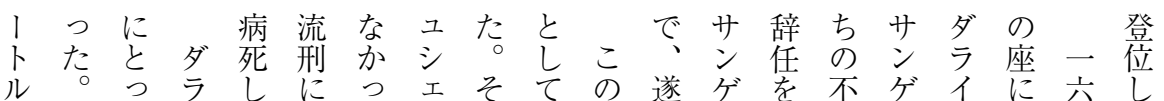

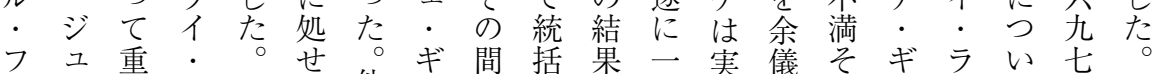

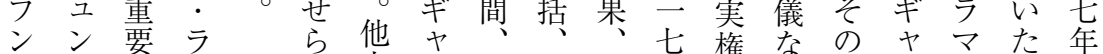

夕ガなマ的方么彼ララ○劣く他么五ラ当

㐱は関五 る る

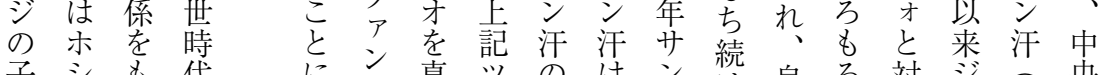

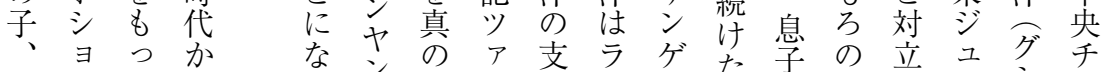

ガトたららうン転ン配サは年ば条関ンジ

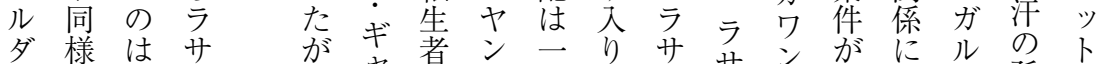

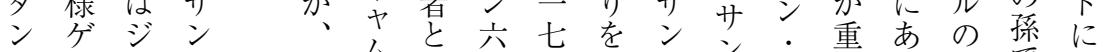

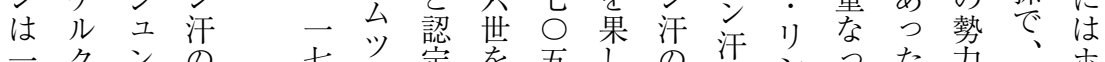

一クンのの窝を五し の

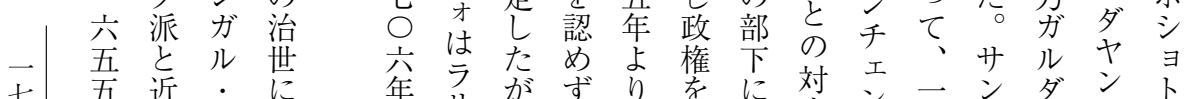

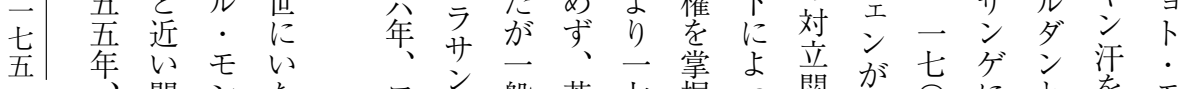

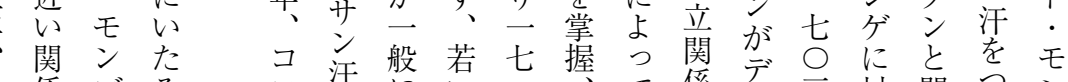

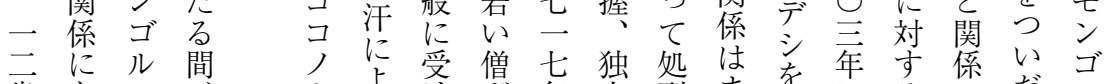

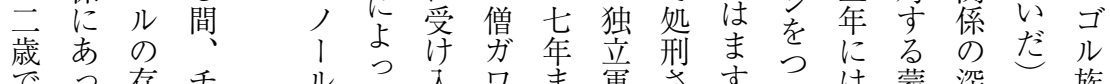

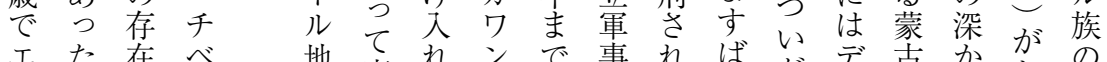

エた在べ地て廃れン望事机ばたデ古か拉の

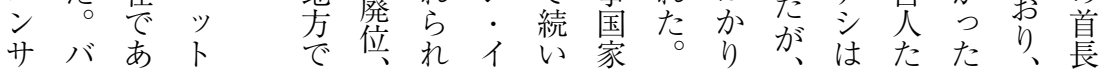



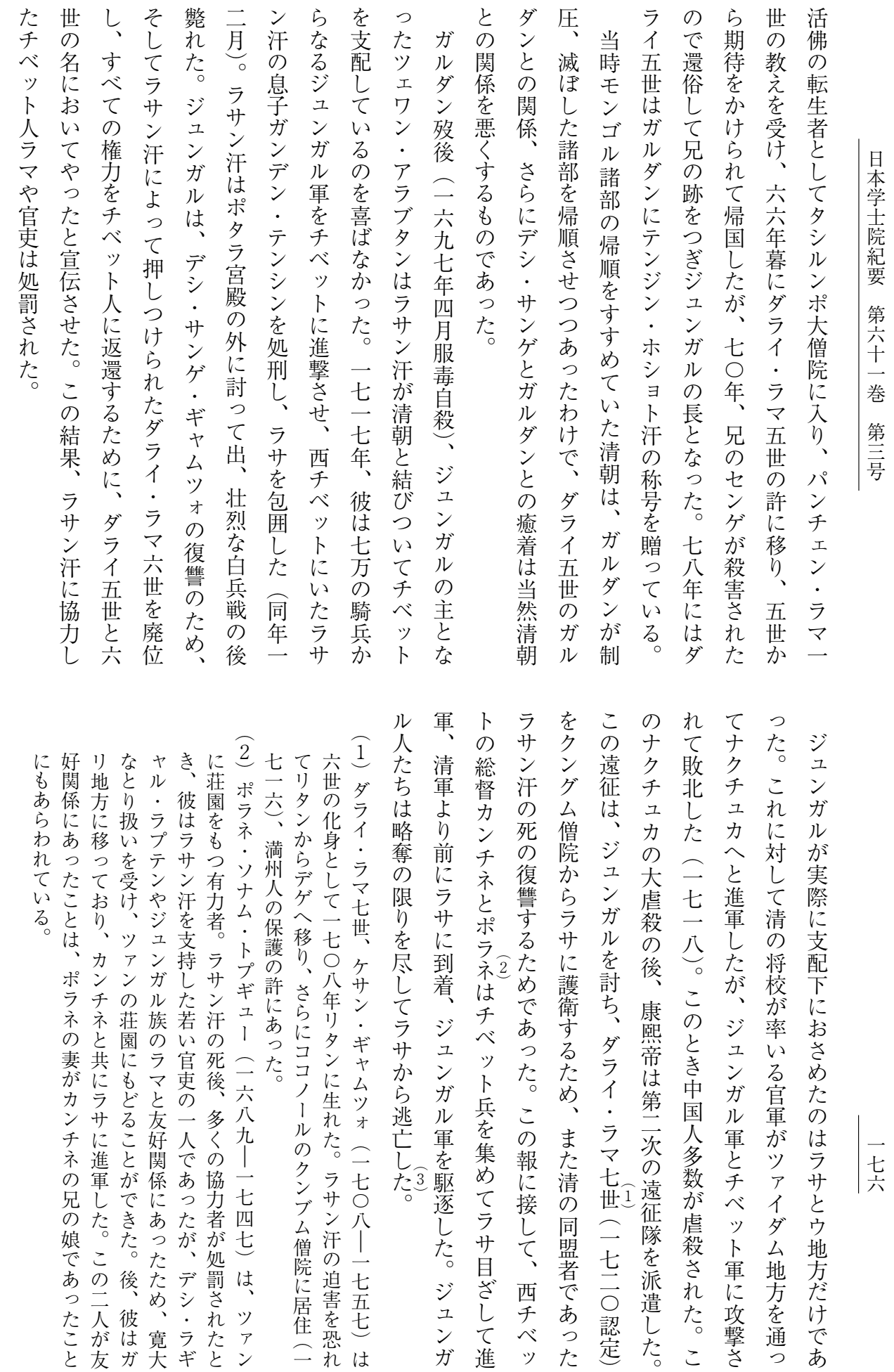

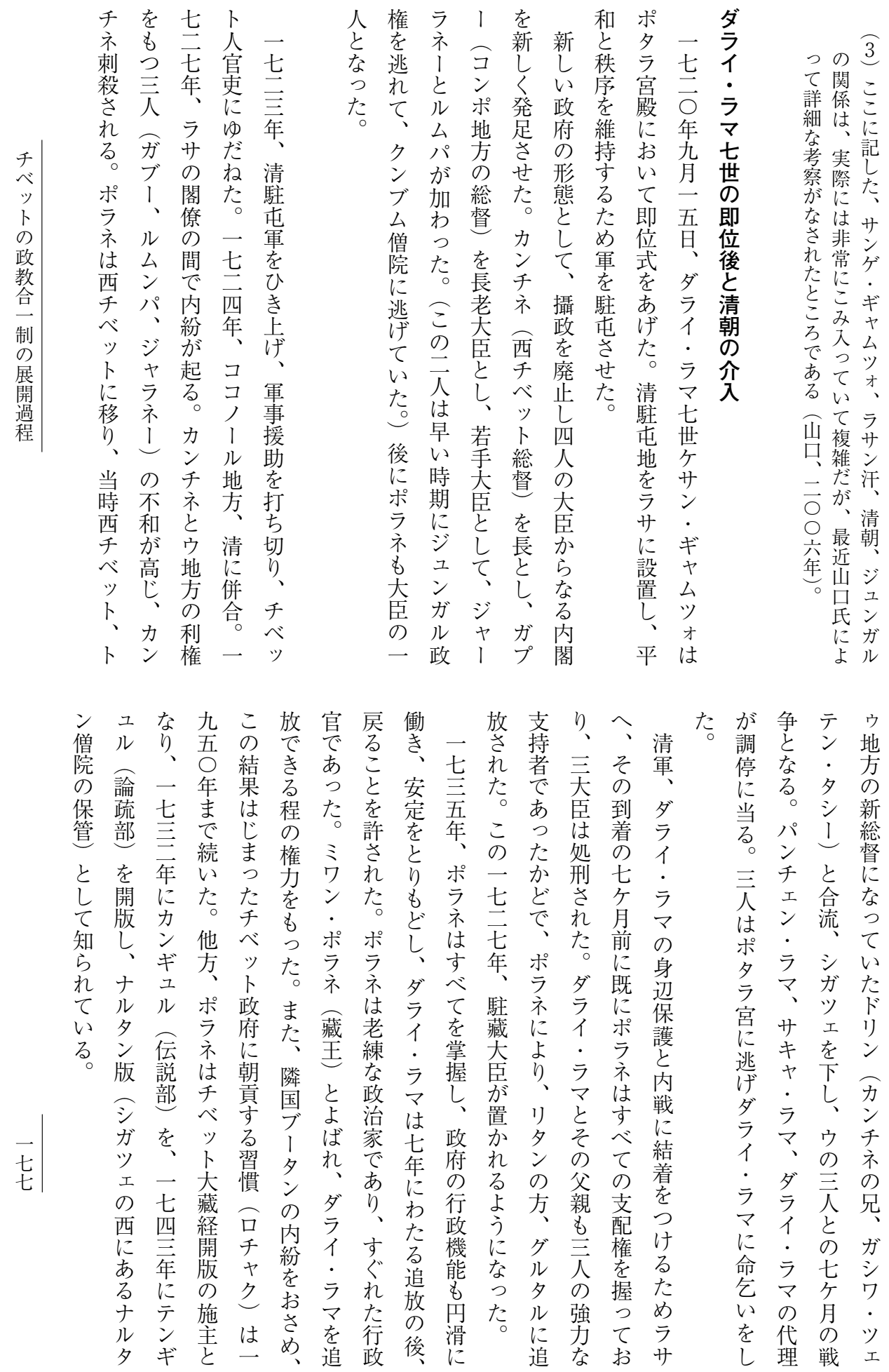

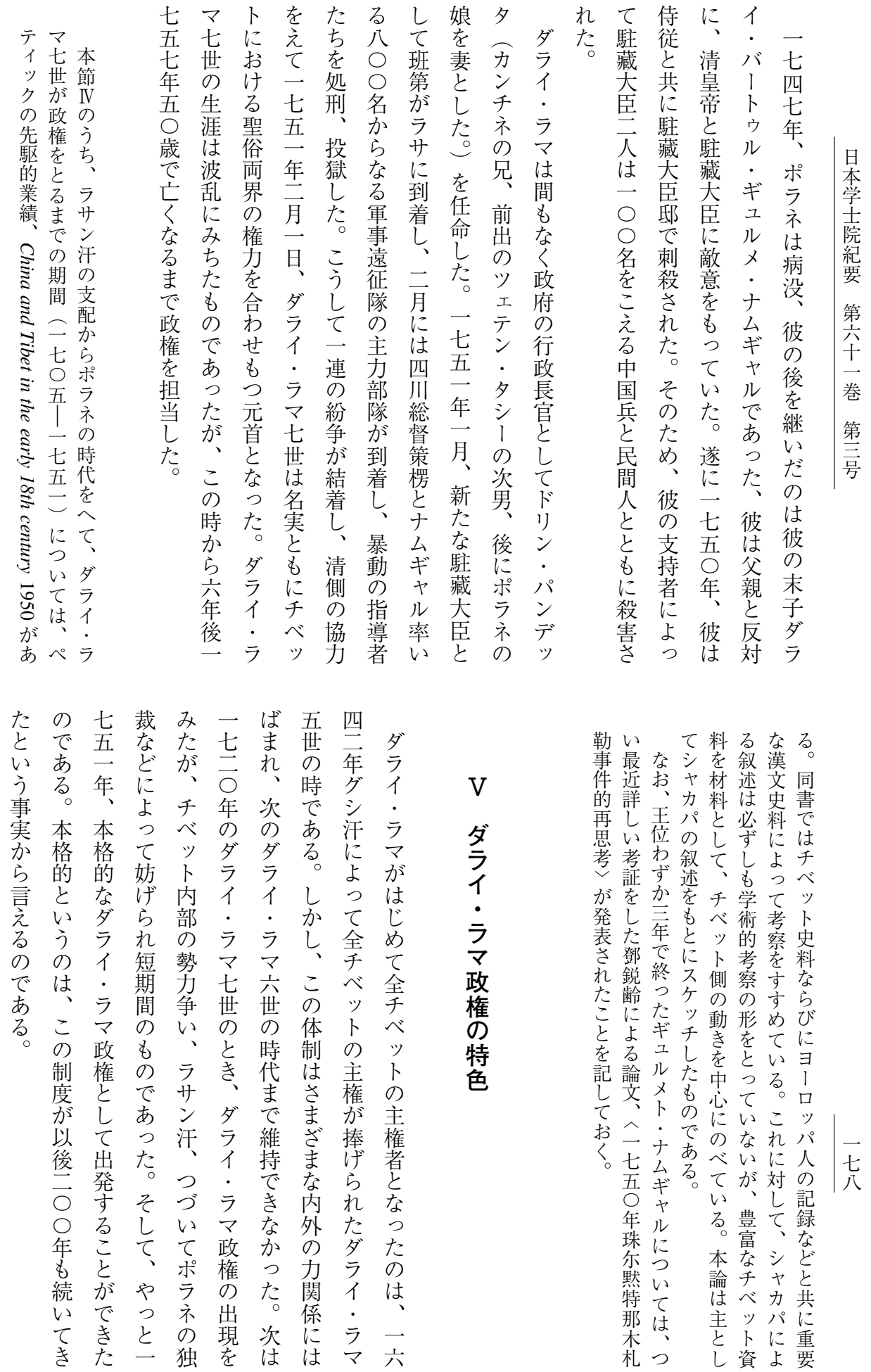


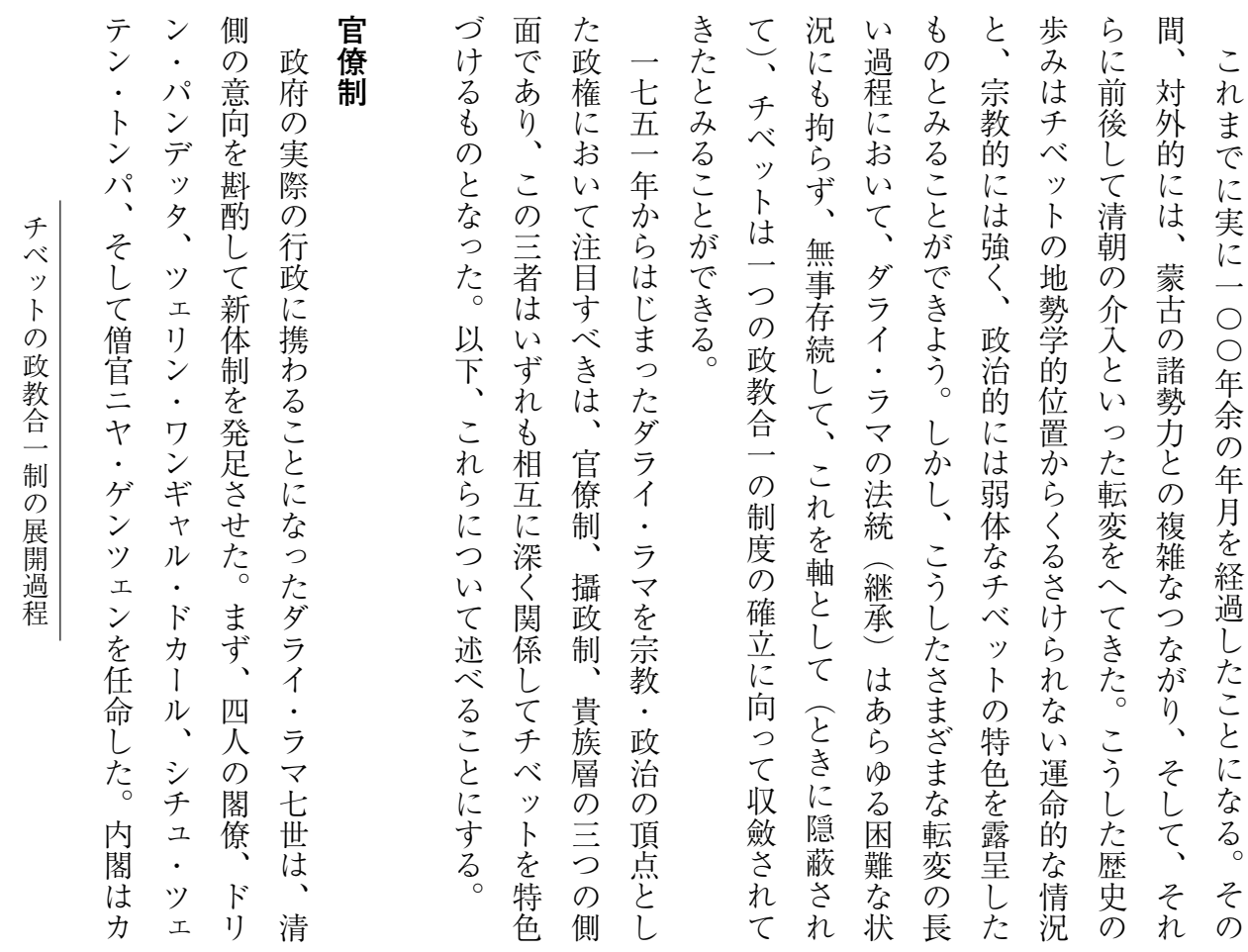

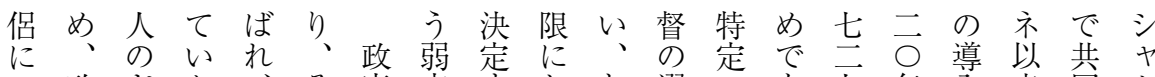
関政ドた、そ府点まとと選のあ王年学来䏌ク、 す府ウ。前のの妾でどい定担つ!にがのし

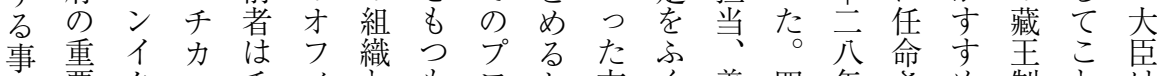

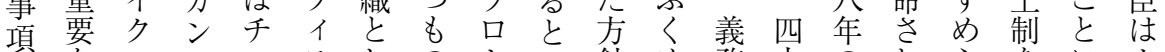
項なの の 担諸于長力はてでスう加てを臣内た排当口

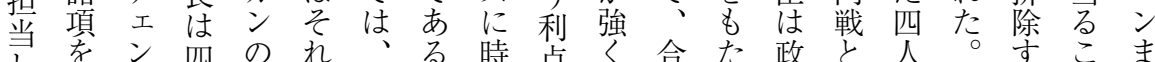

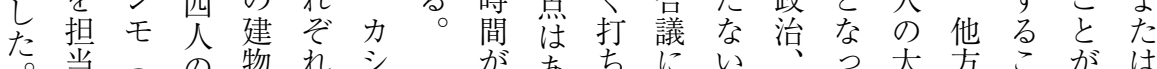

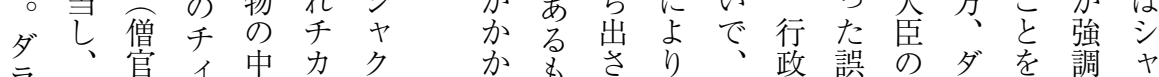

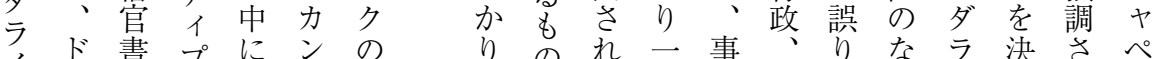

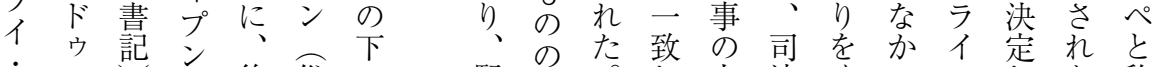

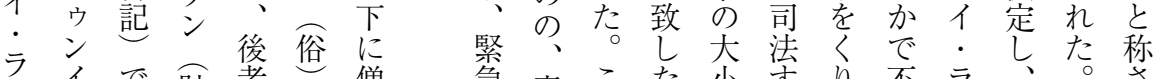

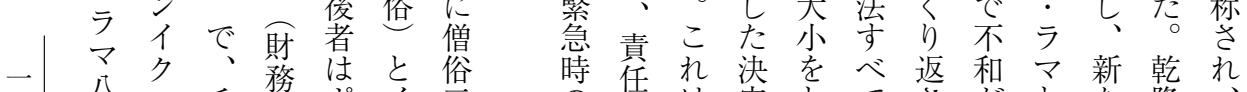
七八

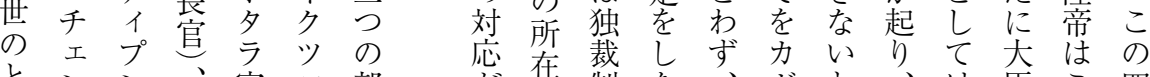

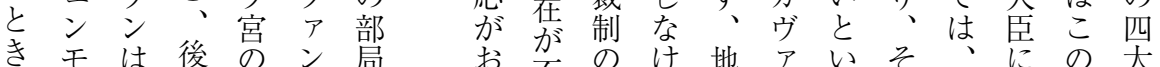

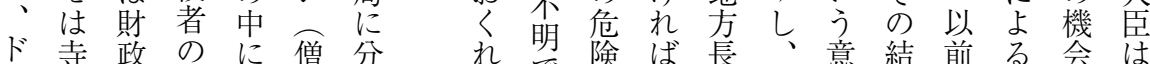
ン院を学長搤じ热 
つ以

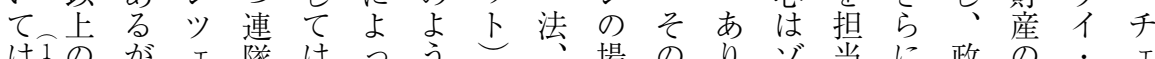

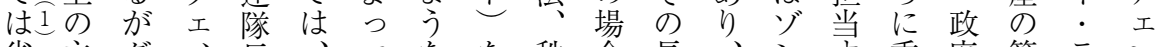

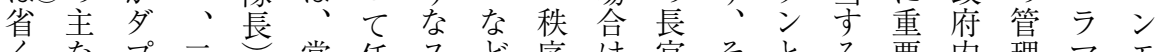

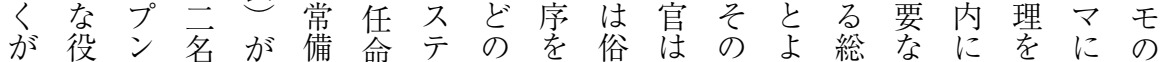
、職とデあ軍の、よ担官原主ば督ポお直上 こを同デりのあ方当二則な机つスいる接位

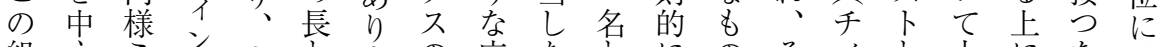

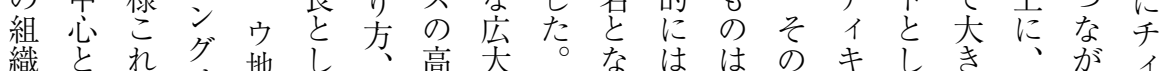

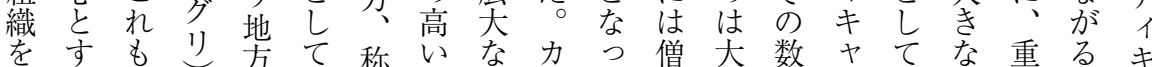
機る俗 に六号俗辺么 て 俗部は数で地影要位キ 能さ官 百名な官境 地い云分五こ方響 事置 プ

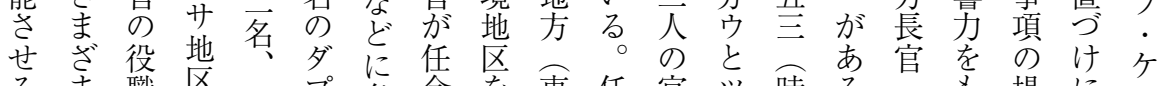

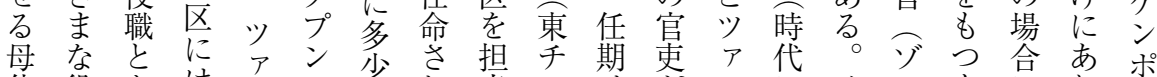
体役な し 職つ

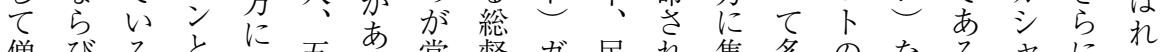

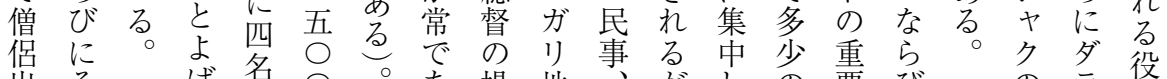

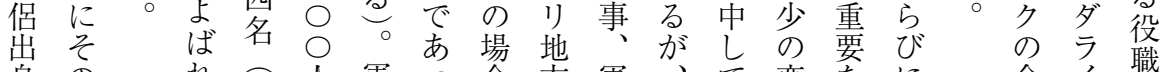

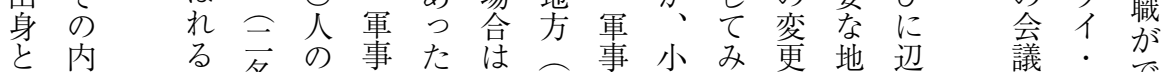

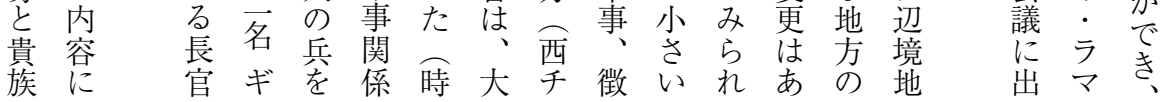

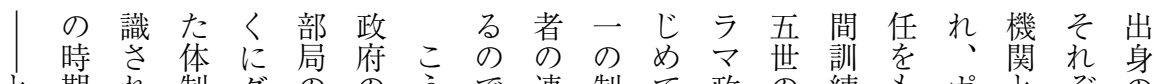
と期れ制名ののうで連制て 政の練も㐫とぞ の

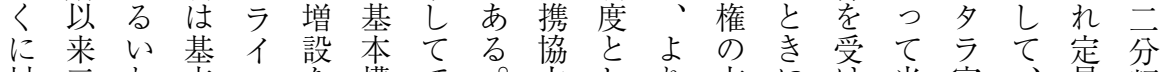
対三わ本・ な構で。㘯しり方にけ当宮、員類 外○ゆ的 ラど造きにて完向設るる内そはが 的世るにマがのた完備は立。新に市

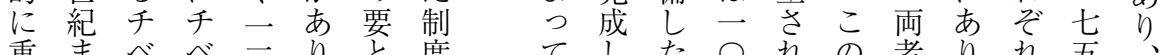

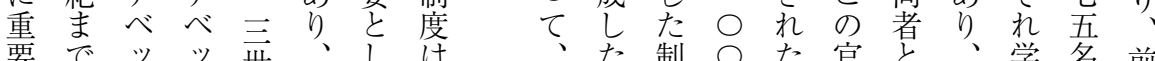
要で、ツ ツ 世 な事内 を 社二襍存々

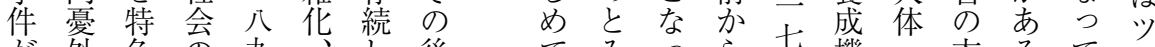
加外色 の 九 起患づあ 五 エ た 二

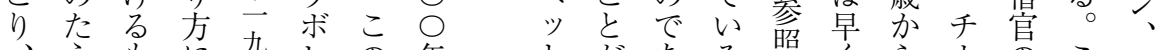

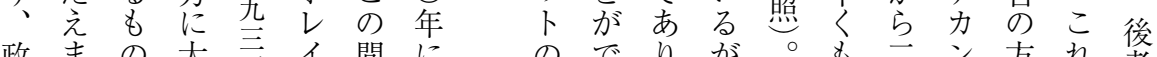

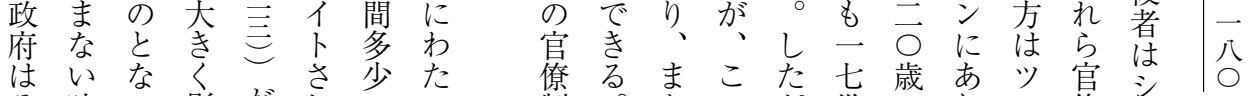

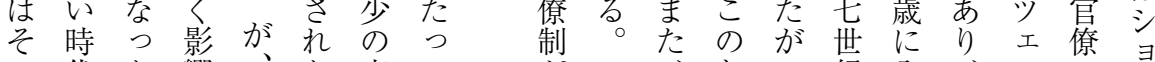

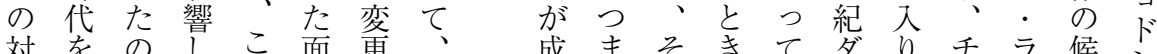

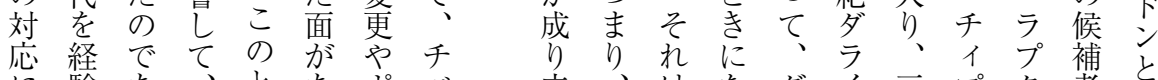
に苦験ある 今 き る

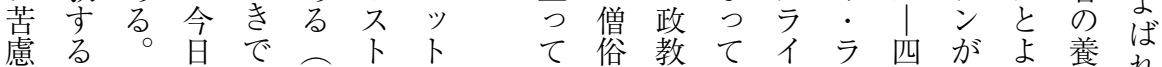

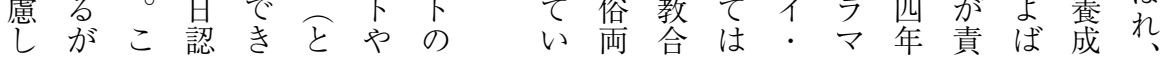




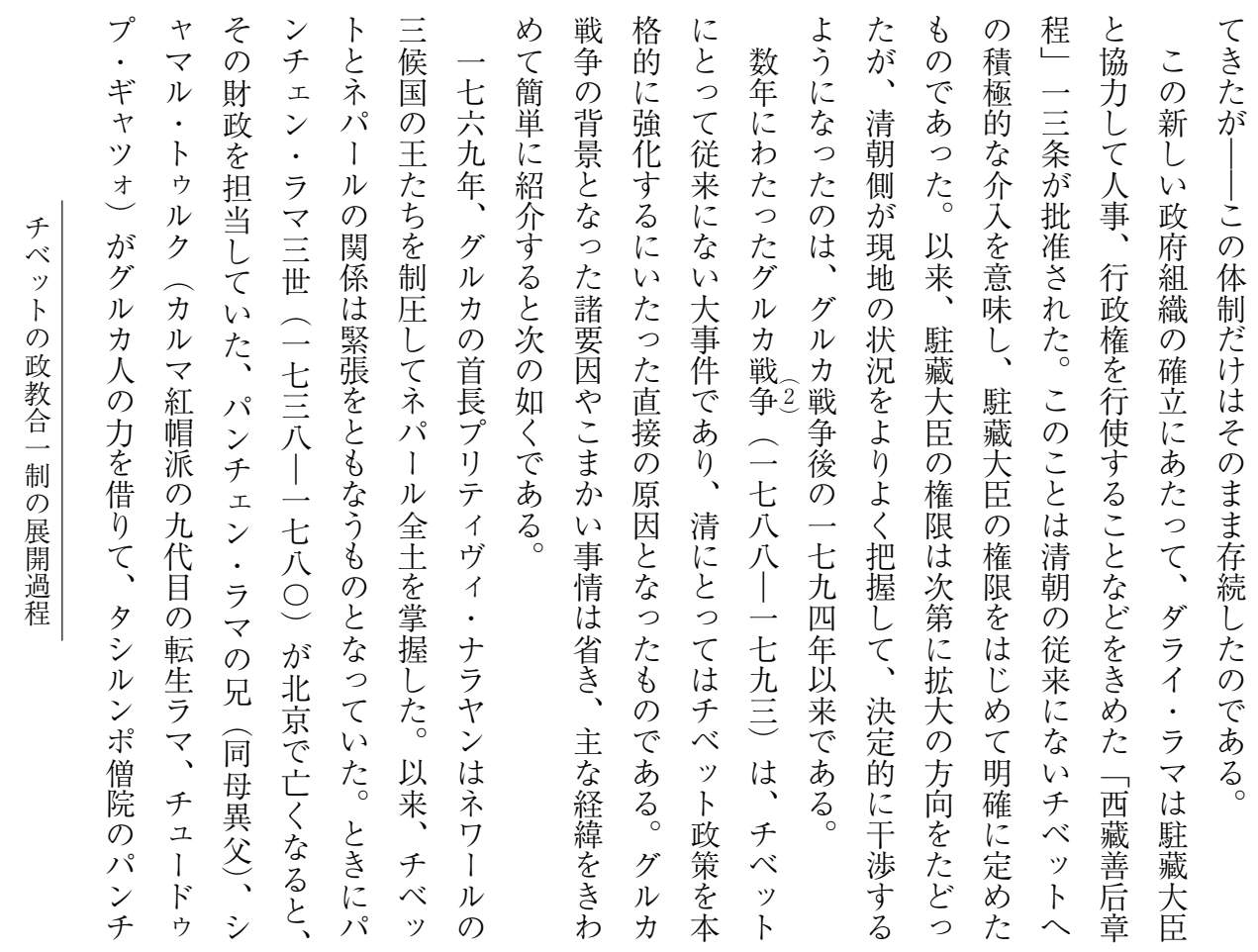

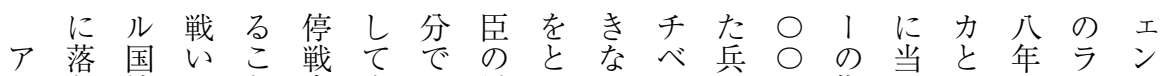

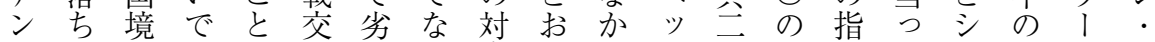

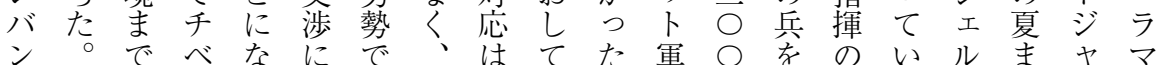

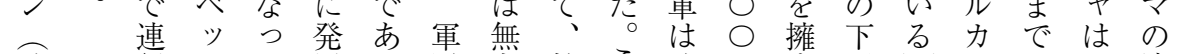

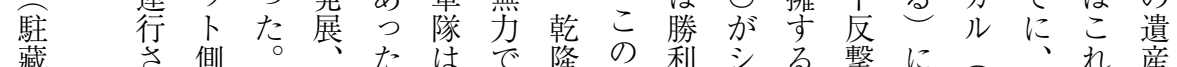

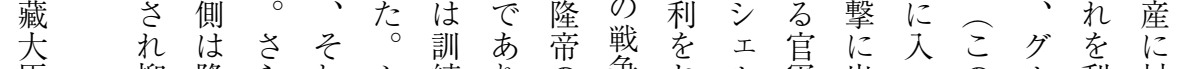
臣抑降ら执や練り只争拈儿寞出つ可利対 留服にはがを、意前さカの、て二カ用す

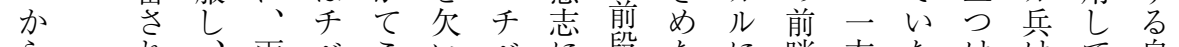

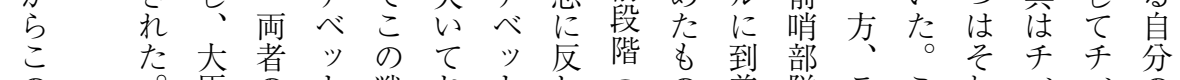
の臣のト戦お京不在の着隊ラこれべべの

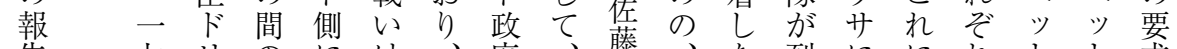

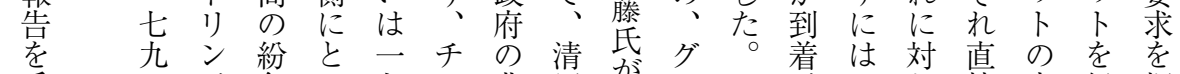

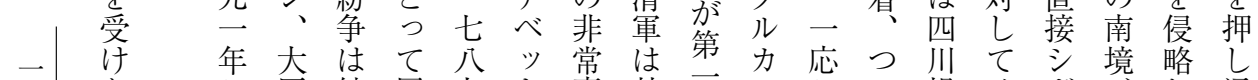

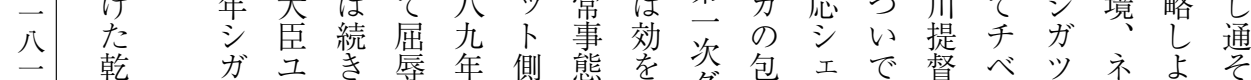

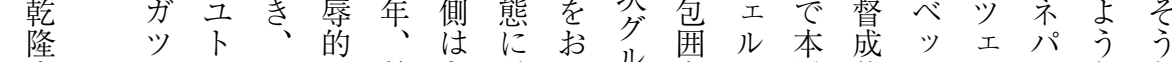

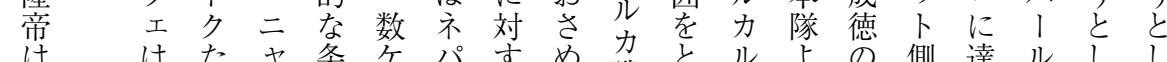
は は た

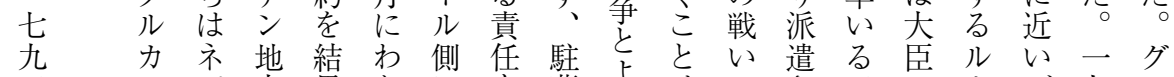

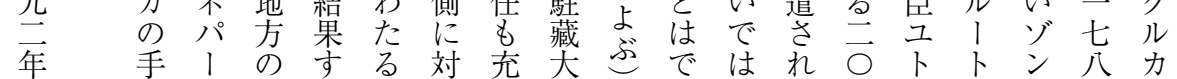



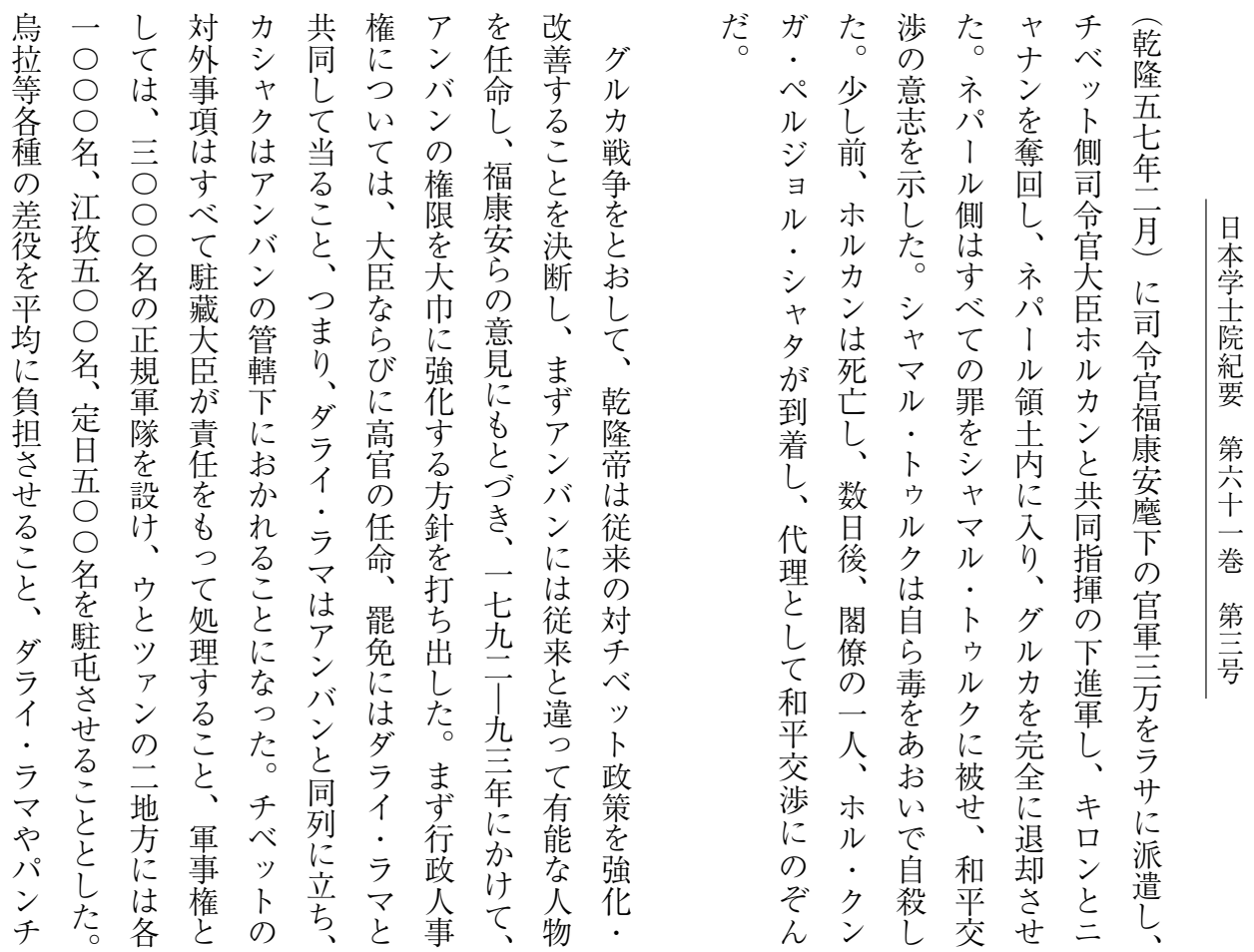

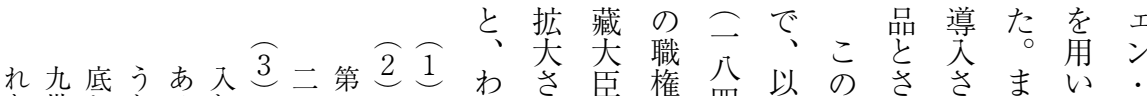

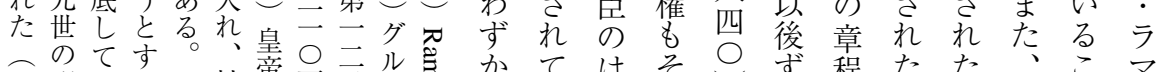

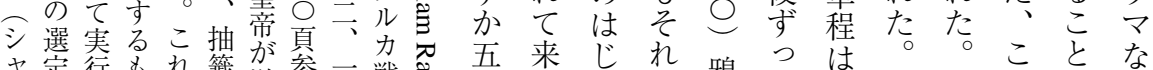

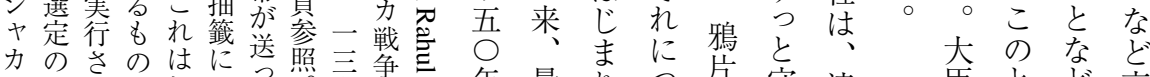

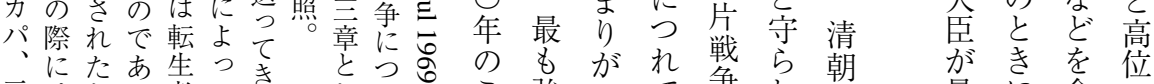
二はとっ者てたしいて強一て争机の朝に最ラ 二候はたの転金てて边と力七弛がて隆高官省 而補言。決生瓶所は兄と云緩起心盛の僚への

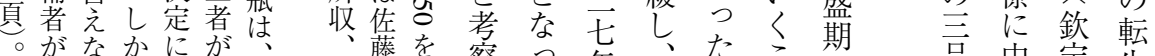

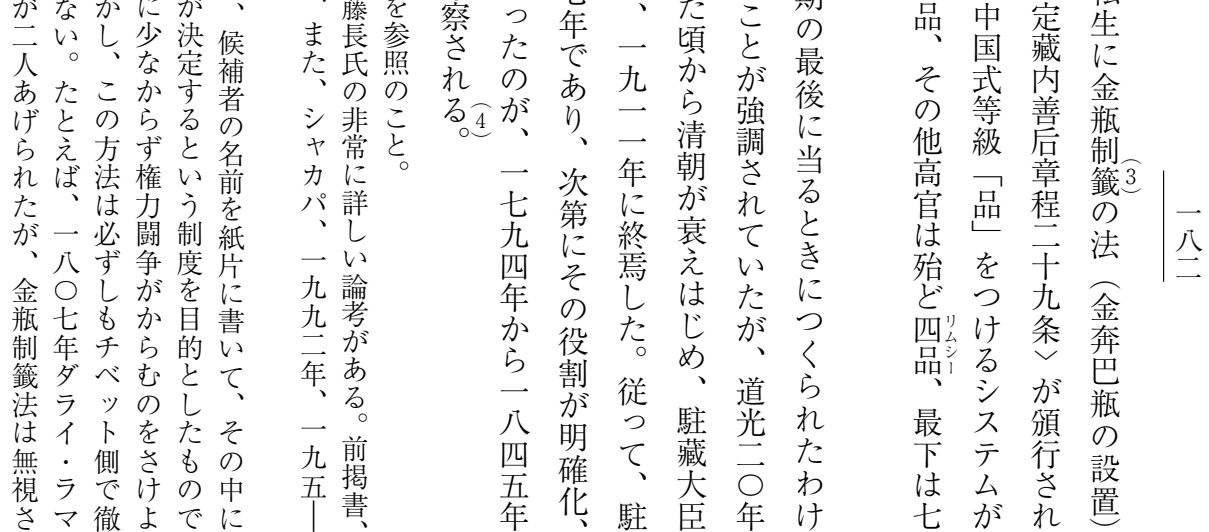




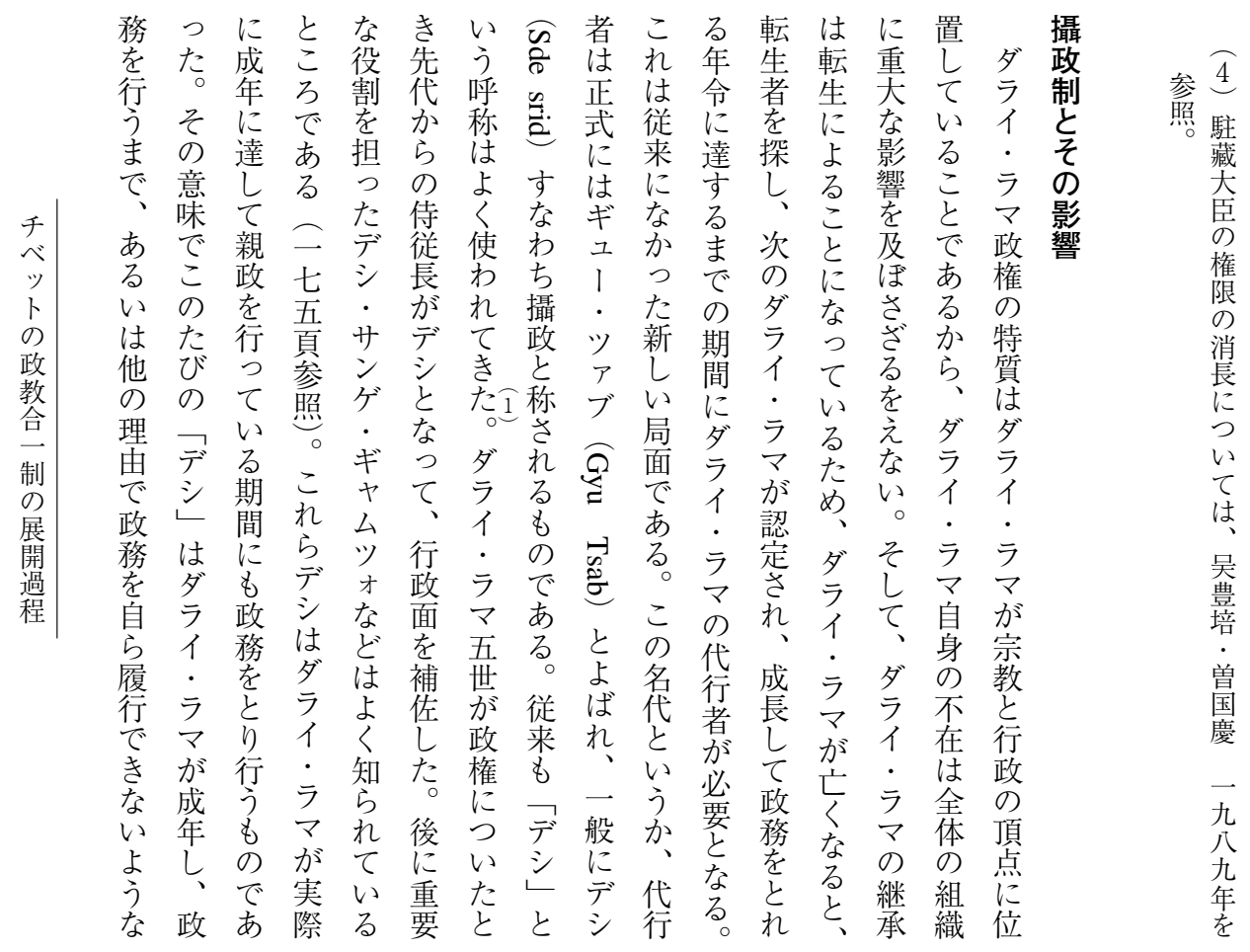




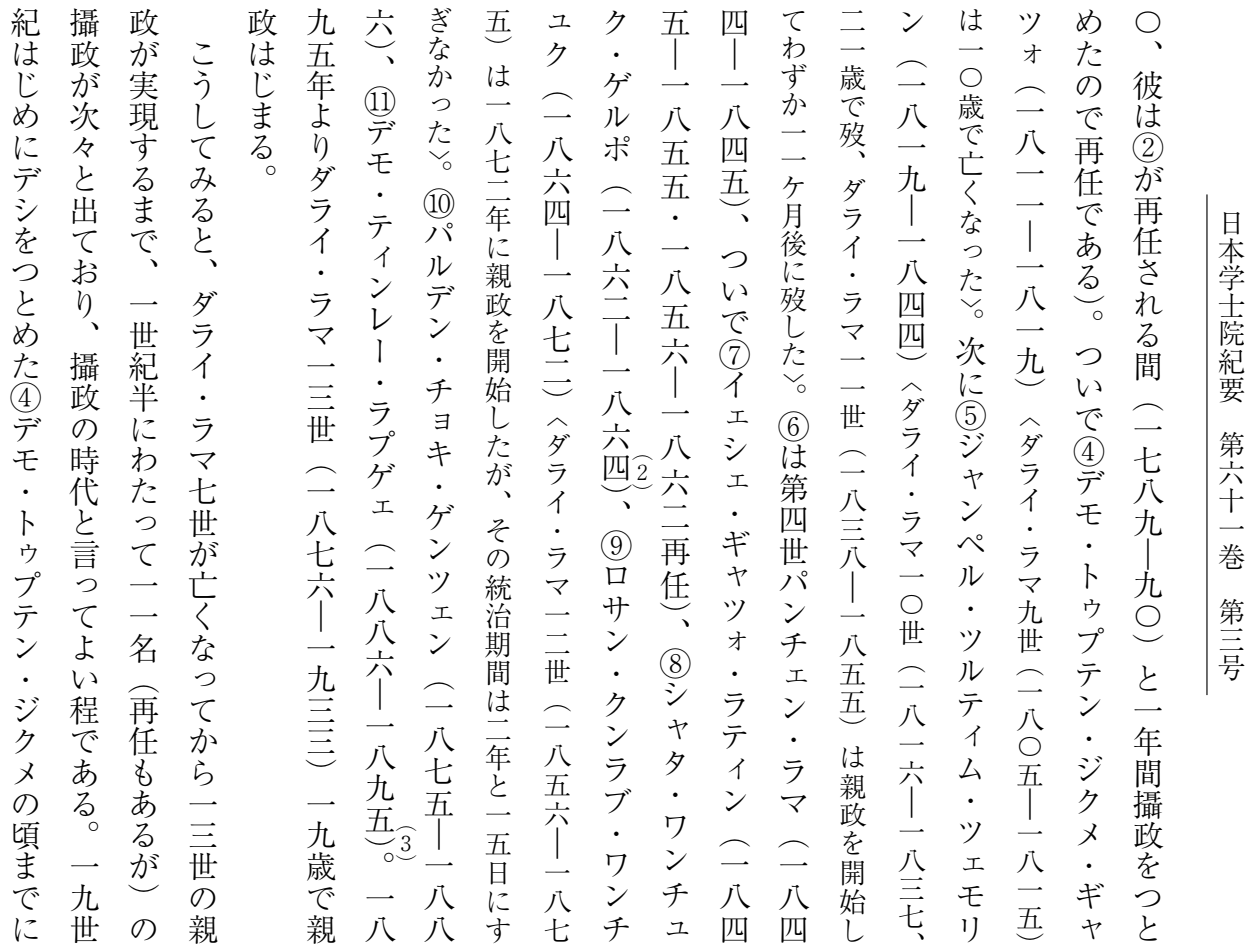

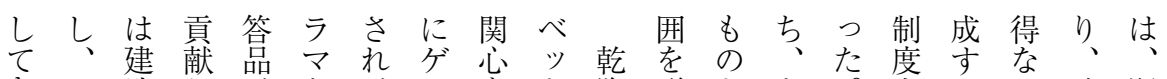

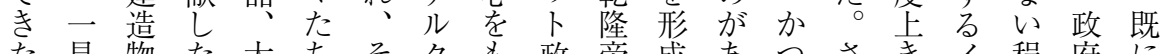
た見物た大ちそク支政帝成あるさき程府に

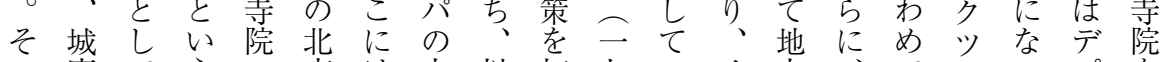
の廓てえへ京は大以打七いチ方、てアてつプ 活をもよのへチ寺前ち言たべかこ独ンてンバ 動めそう寄のべ院に出吾のツられ立のい、、 もぐの。進往ッ文しけで卜留ら性管たセク 広ら偉ま寻来卜雍まて二市中学大架轄とラ、

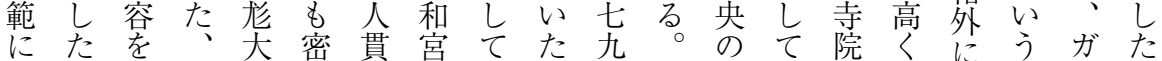

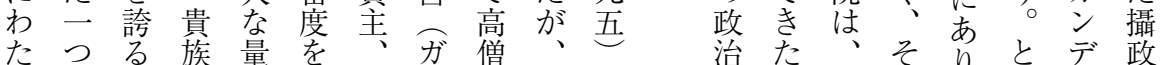

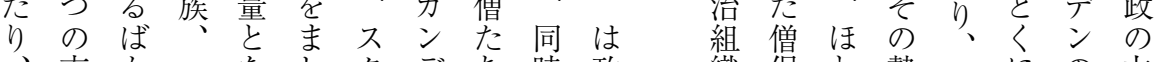
、市か一なじ夕デち 時政織侣と勢名にの力 宗街り般り、ッンをに治のたん少ラこ僧は

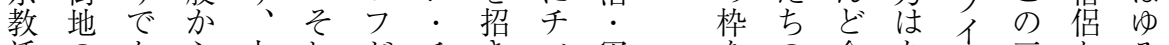
活のなら大れがチきべ軍をの全あ! 言たる

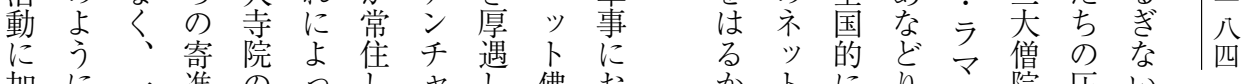
加に一進のつしヤし佛お拈ににり院圧い

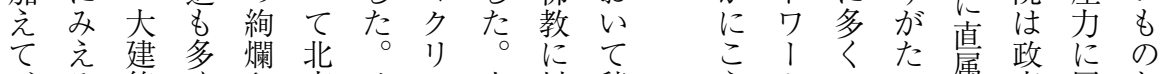

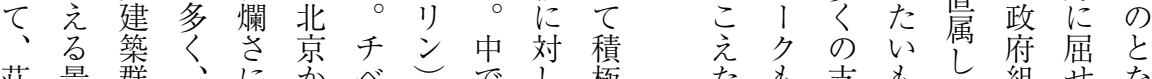

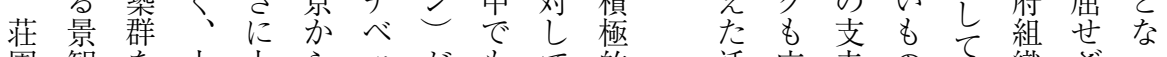

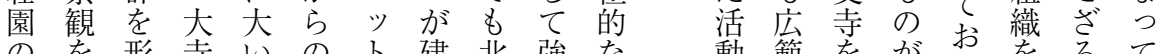

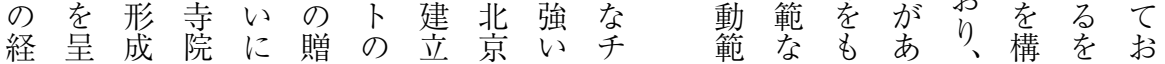



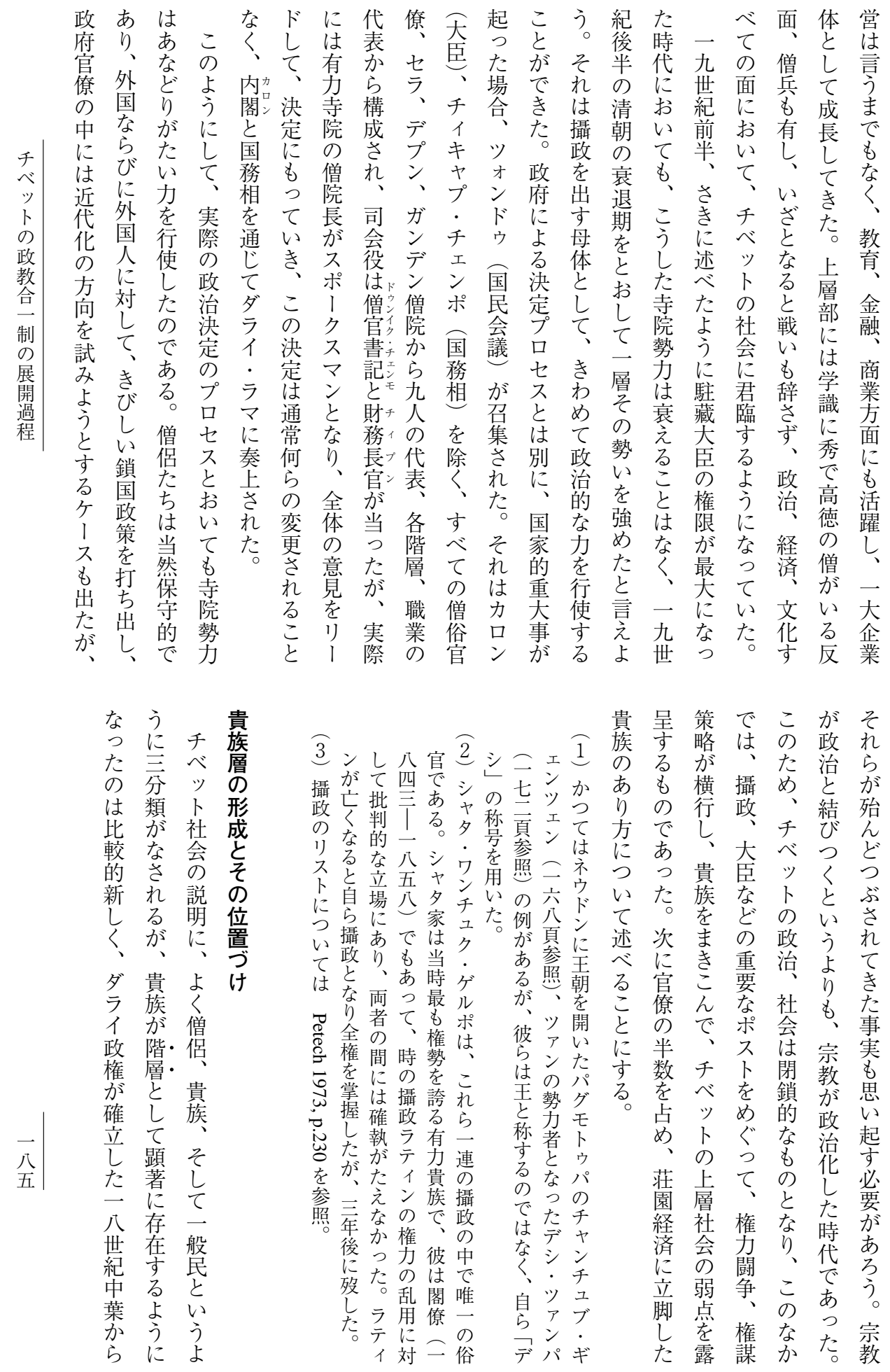
ン、タラに カ 八がをダタドら後!六、、年あ頃めれ れれ世

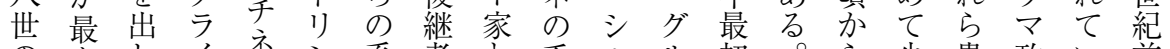
のもしイ不ン系者と系ヤ初。ら少貴政い前

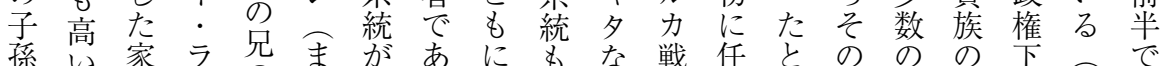
は䋆い家 マ の

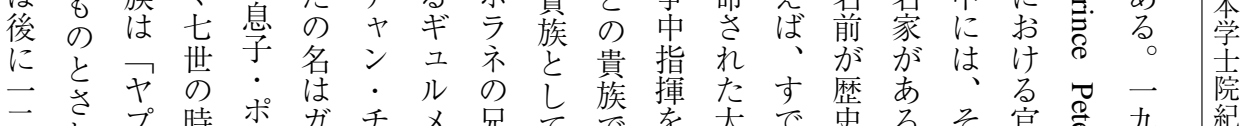
世云 れ プ 時 ボガ チ メ 兄 て で を 大

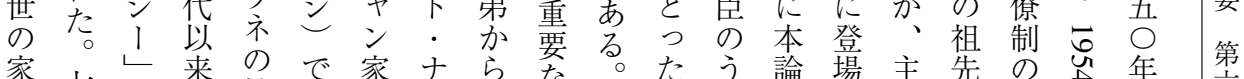
家七族世望 合茨称 ま

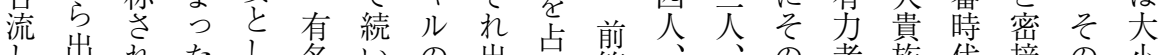

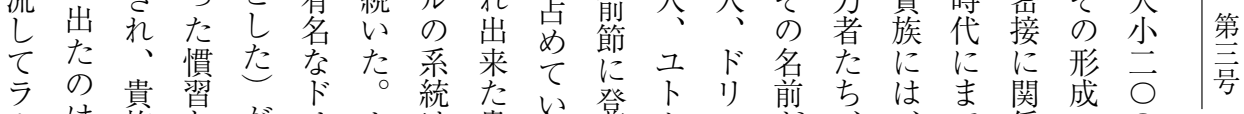

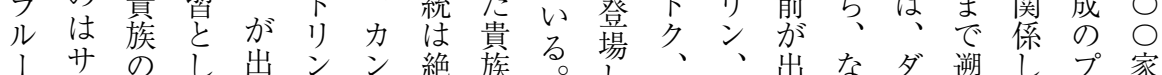

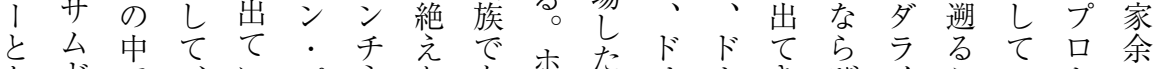

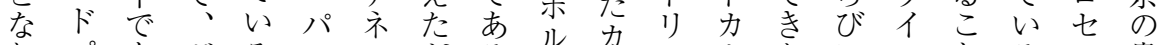
りプも ダる ン の がる

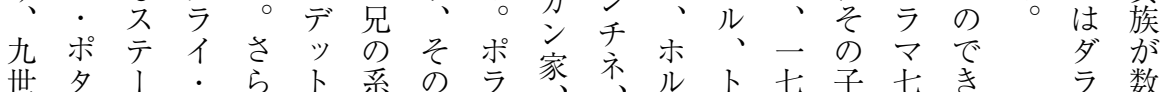

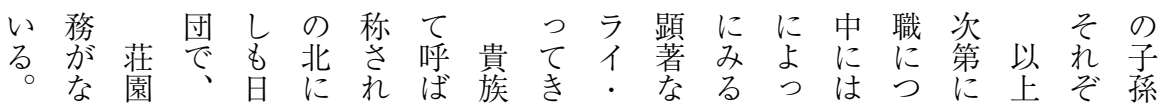
中いは英本あるれのた产階とて不き登のれれは に代ゾ語のるる゙る名。マ層、加幸、場よ続絶

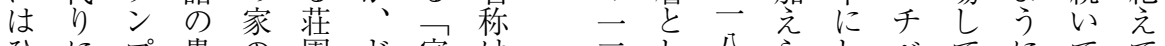

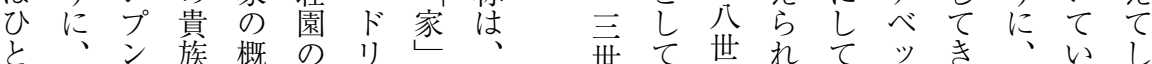
と一ン 族

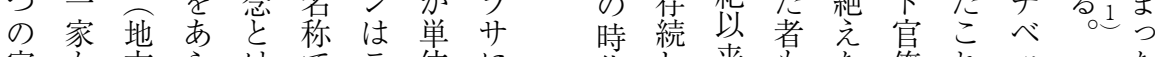

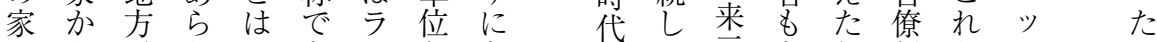
か ら 少官 す

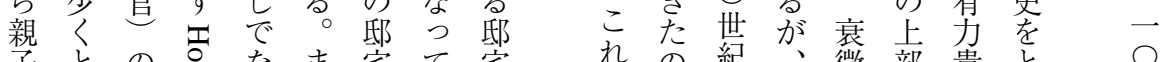

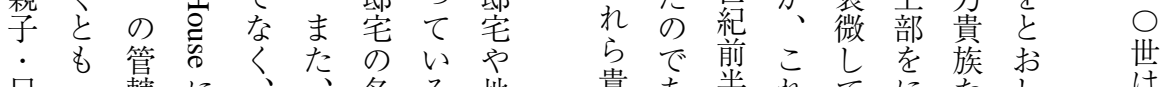
兄一轄に、名る地に貴あ半れてになし な弟人外近 よここ称方

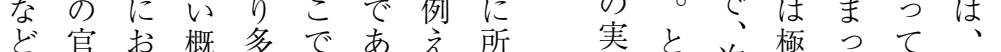

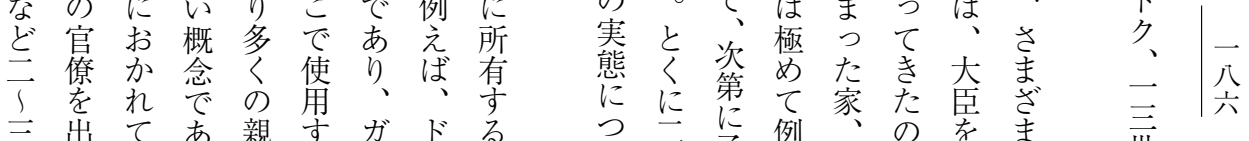

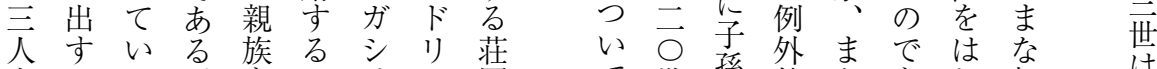

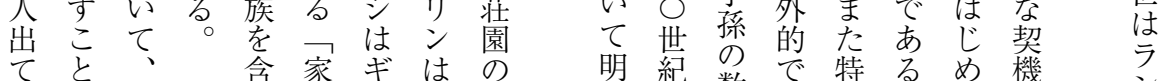

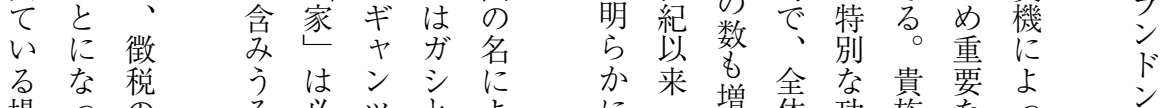

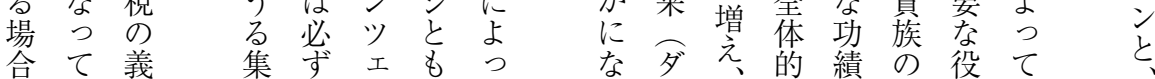


図 4 AFFINAL RELATIONS AMONG INFLUENTIAL 24 FAMILIES

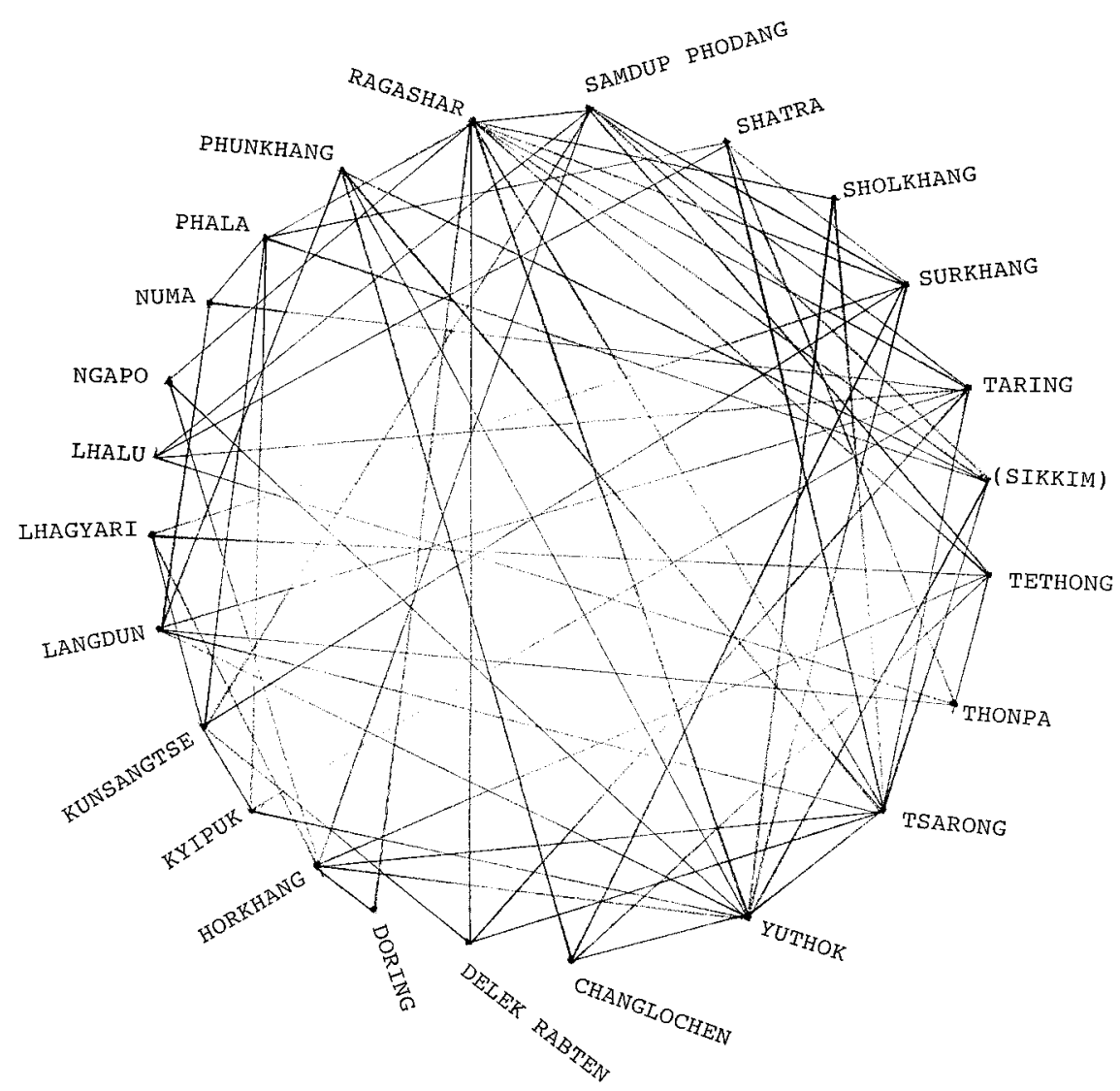

八
七

From : Nakane Chie, 1992 


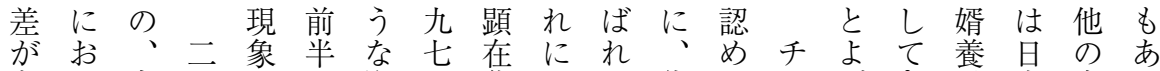

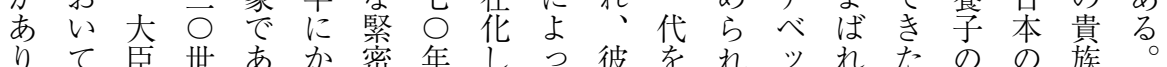

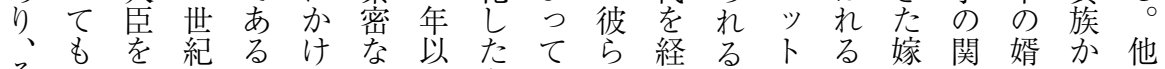

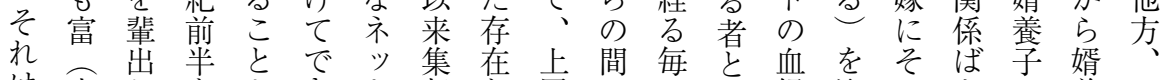

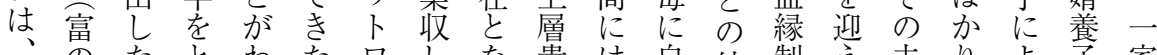
かのたとわたワしな貴は自結制え夫りょ子家

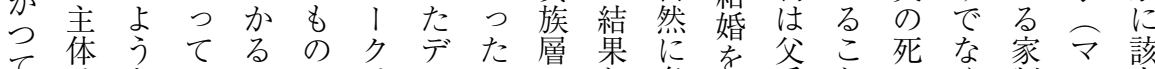

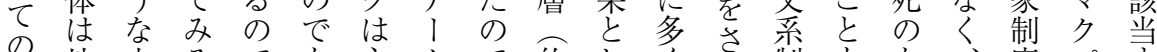

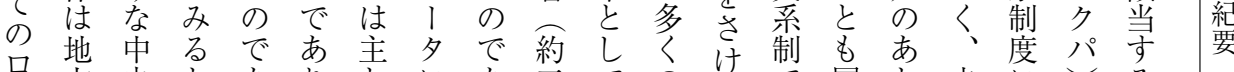

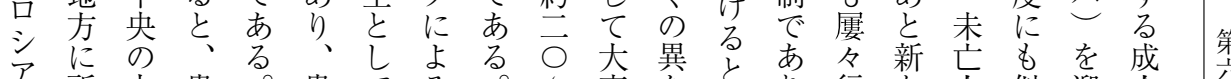

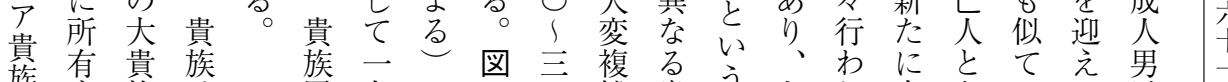
族㠻族

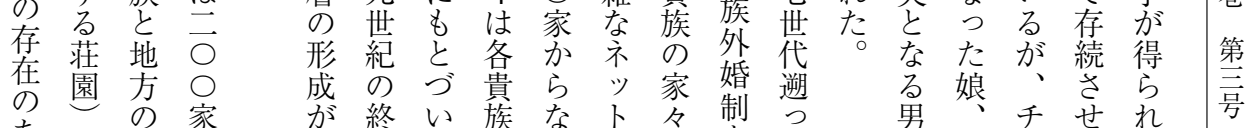

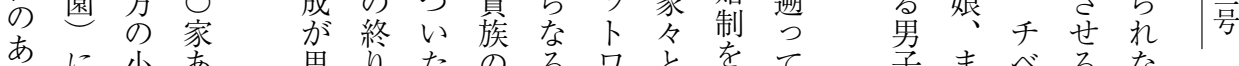
りに市思少た

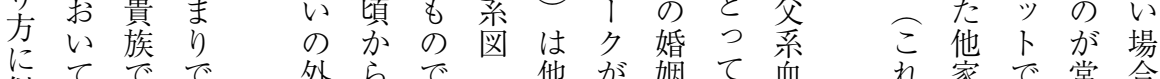

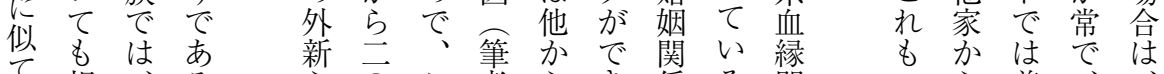

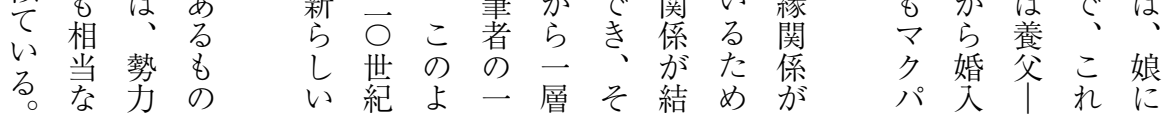

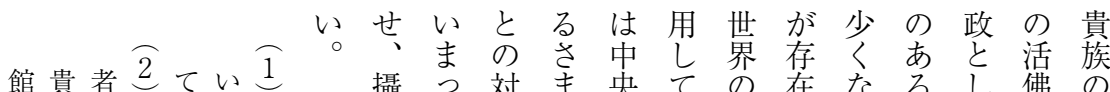

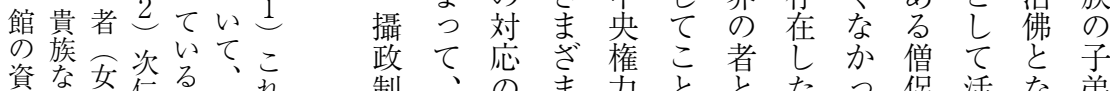

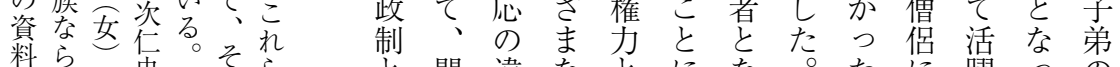

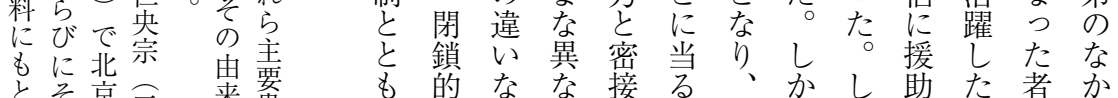
と京二来賈も的なな接る、かし助た者か

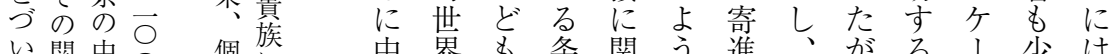
い関中○個族中界も条関う進、がる|少は て係国五名つ央の含件係な貴つばスく当

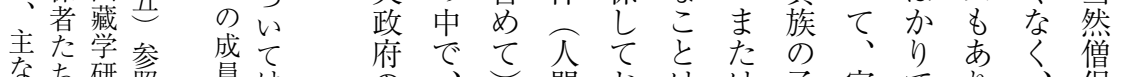

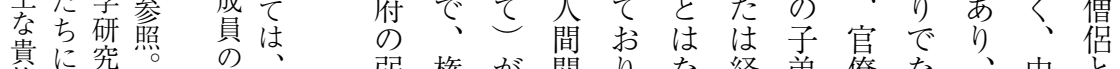
罷究。政ぺ弱権が関りな経弟僚な、中号

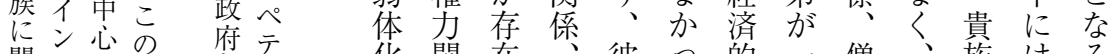
関多心著集テ化闘在彼つ的一僧、族はる

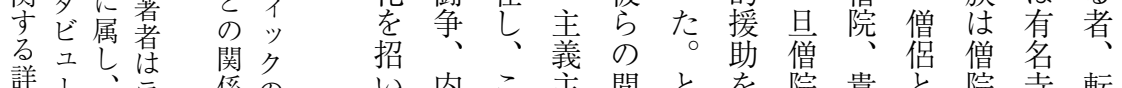

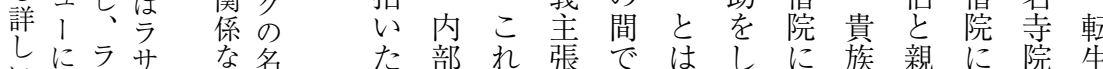

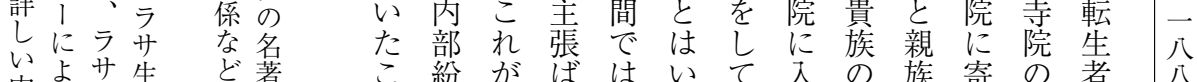

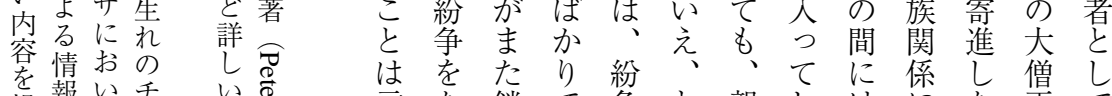

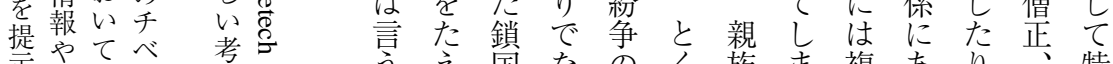

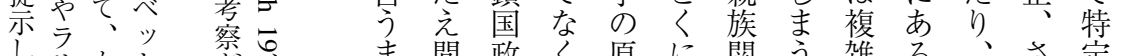

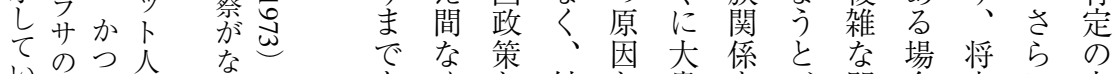

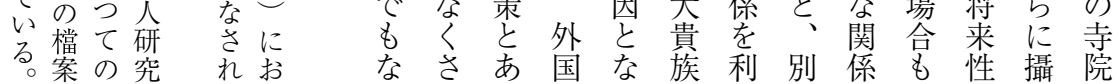




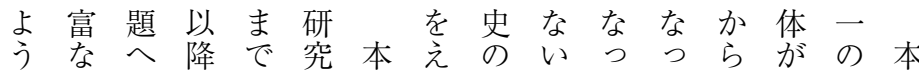
に資のこはの論な中かて成論

な料関二成のいでもお起䟎は

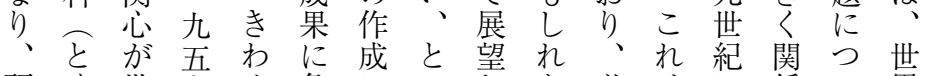

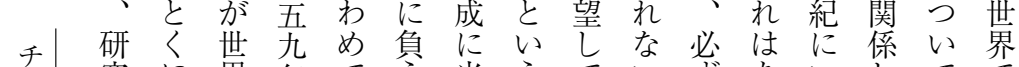

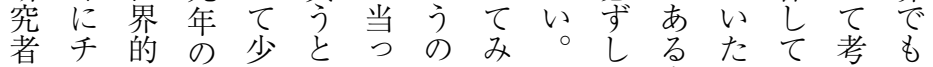

のべにダ数こて がるしもも意る い察独

数ツ高 ラのろは筆と、か他味歴る 学得

も卜まイ学が、者、ししので史と試な

増文つ・者多このど、チ筆過いみ展

え献たラにいれ立う政べ者程うた開

チにと学の つ チ

ベ研とイてべのあも立研べ要者でを

究同ン進 ツ多る。こと究 少最観、も

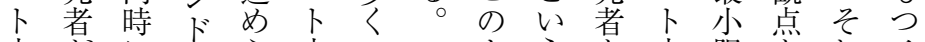

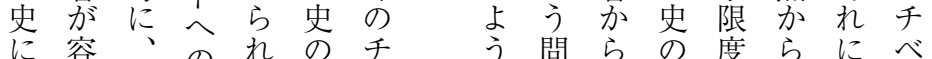

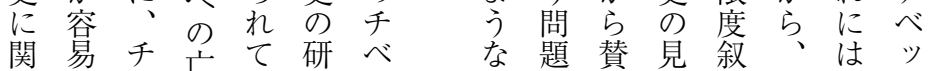

守にべ命き究ッ理を嘼方述結チ十

るアッ命たはト解大をををに果べに

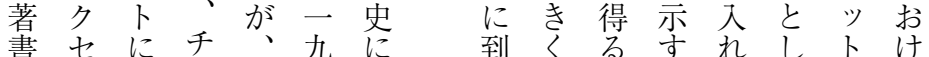

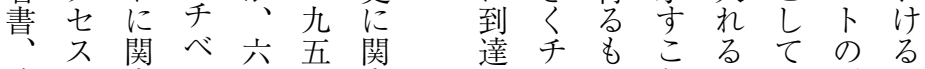

論です

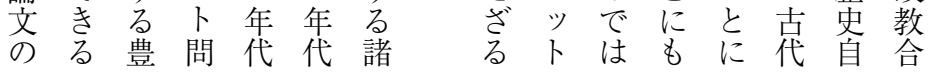

る教 み 僧仰存に に

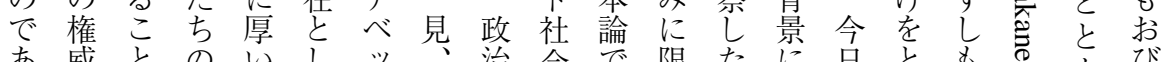

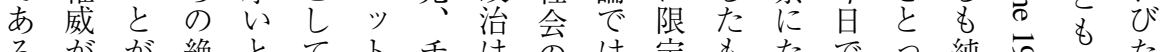

る 柺が絶と皇

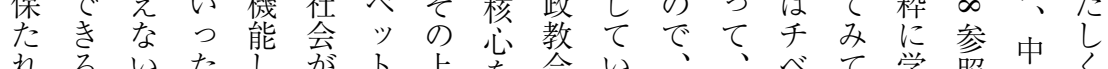

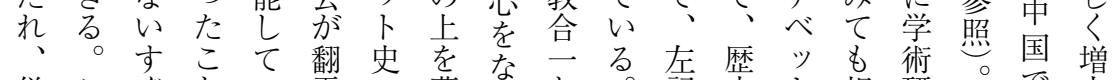

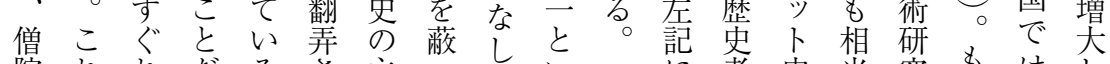

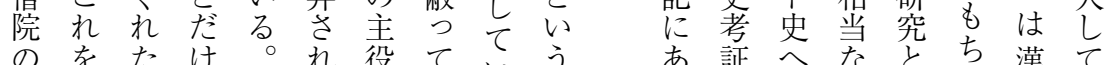

のを社バ知でこ て

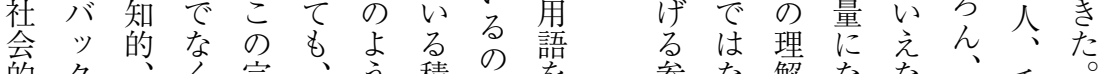

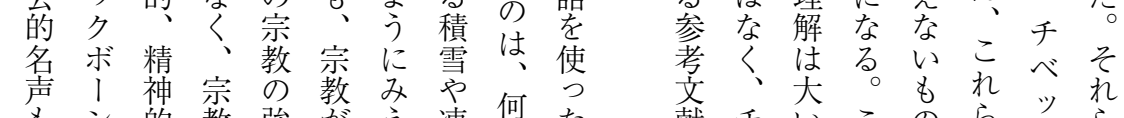

もン 的教強がえ 凍何た献チいこのらツら

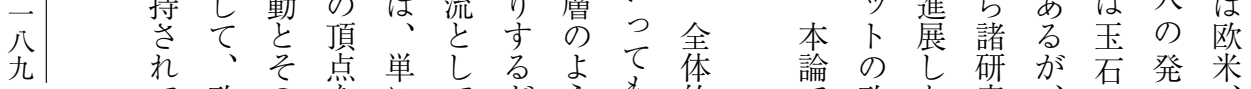

て 政の点単してる よ

き治成形千更

たを果成 ベなない存教 み

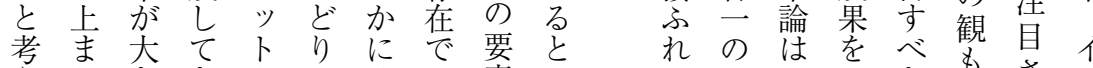

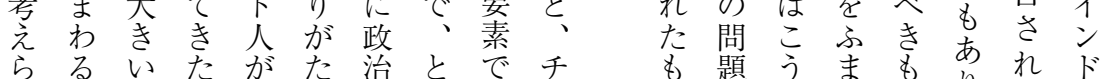

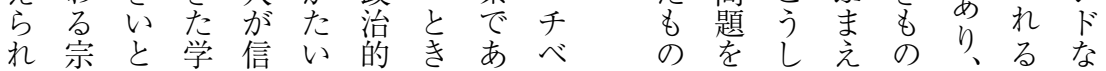



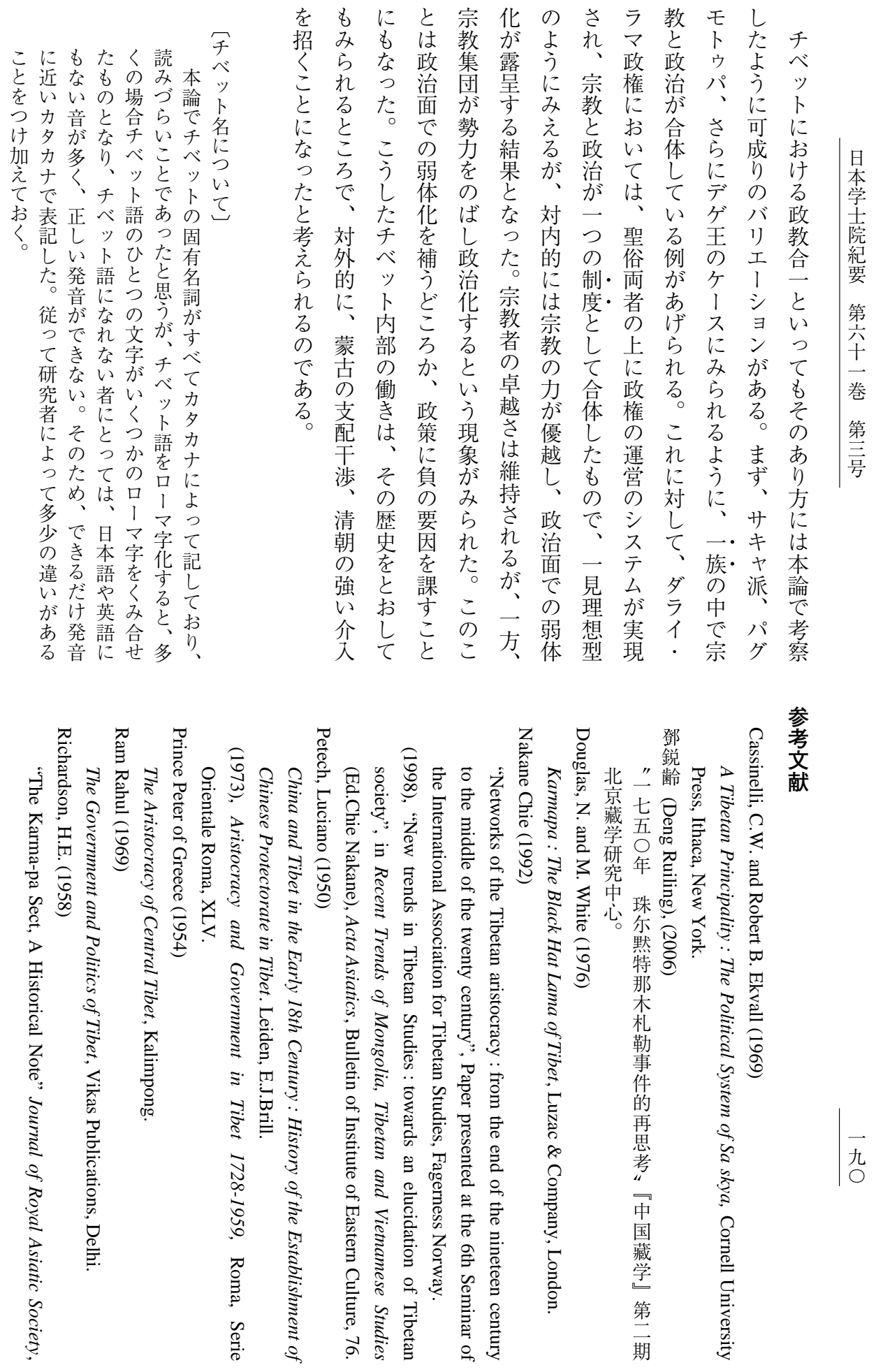


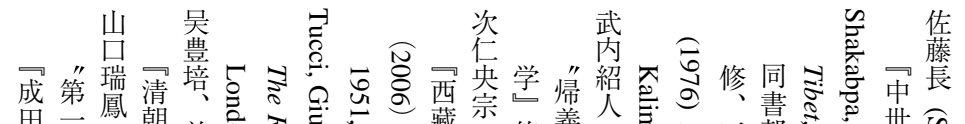

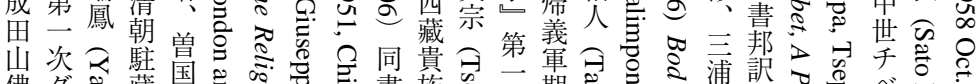

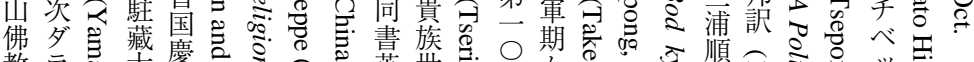

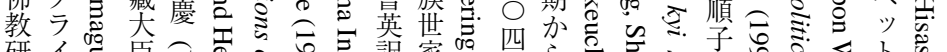
研

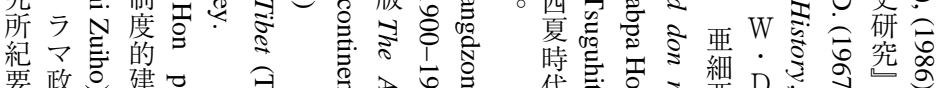

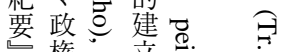

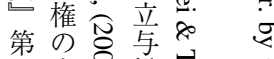
崩要沿 $\overrightarrow{0}$ 旮壊革要

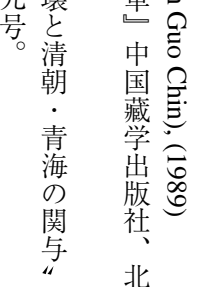

$\stackrel{9}{\square}$

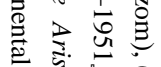

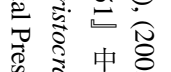

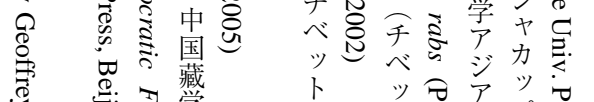

代泀要要 $\mathrm{D}$

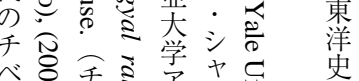

कृ.

語点它勇パ预

产焉版

語突究金

。

氵

書

元 ‡ 北

紧

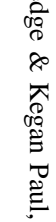

इ

ベ

語

景

吕治

灾 貞 舎

त

Ð

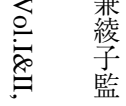

九 
religious and political institution. However, this Dalai Lama polity was not to last. Until 1750, Tibet suffered from internal as well as external infightings, disturbed by Mongol powers that had joined with one or more Tibetan powers jumbled together religious sects, and interventions by Manchu power. During this period, political elements came to the fore.

Newly established in 1750, the Tibetan govenment lasted 200 years, assuming a concrete form of politico-religious unity as an institution. The organization was divided into two departments of monks and lay officials, each having 175 men. Important posts were occupied equally by monks and nobles. For example, appointments to Dzongpon (district magistrates) of important areas were given to two officers (a monk and noble) jointly. This is indeed a unique system, one in which the traditional Tibetan value system (politicoreligious unity) had converged into an established institutional form under the Dalai Lama, who stands at the apex of the organization as the politico-religous head.

What is called Tibet politico-religious unity or amalgamation took the form of various arrangements. One was the cases of the Saskya and Phagmo grupa : the roles of religion (religious head) and politics (administrative authority) were carried out within a particular family lineage. In another, the religious heads were succeeded by incarnated lamas of their predecessors, the system of which was first adopted by Karmapa and introduced by Gelugpa and others. This system entailed a consolidation of the religious institution, but was prone to be linked with a particular political group. As the final arrangement, Tibet produced the well-known Dalai Lama polity.

Looking back throughout the history of Tibet, the heart of Tibet lies in religion, where as politics can be likened unto a snowbound or permafrost zone over the land. In certain periods or under particular conditions, politics may appear to be a major actor with in Tibetan history. Whenever Tibetan society was at the mercy of politics, however religion has functioned with not a small magnitude of strength. This strength of religion (religious elements) is not attributed only to the pious belief of the Tibetan people, but also to the great intellectual contributions and spiritual activities of the ever-present great monks. With these works as the backbone of Tibetan society, the religious power and social reputation of the monastic institutions have been maintained, allowing them to prevail over politics. 
Buddhism. I do think the reason why Buddhism has become rooted so deeply and has continued all the way in Tibet can be attributed to this period when the firm basis for religious society was formed there.

It was also during this period when the Mongols were growing in power from Chingis khan (1162-1227) to Kublai khan (1215-1294). Growing monastic powers in Tibet began to look to building relationships with this huge military power. After invading Tibet the Mongols soon became concerned about Tibetan Buddhism and major monk leaders. The first invitation from the Mongols (Prince Goden) was sent to Saskya Pandit, who arrived in Lanchow (Goden's camp) in 1247. Having deep respect for him, Goden offered Saskya Pandit political supremacy over Tibet. Later, in 1253, his nephew Phakspa was invited by Kublai khan. Impressed by Phakspa's religious performances, Kublai offered him governing rights over Central Tibet, Kham and Amdo, and also the title Tishri. The actual administrative role was assigned to Ponchen (governor general). The territory of Tibet was divided into 13 cholkha, each of which was divided again into 10,000 units (tikhol). A population census was introduced for the purpose of collecting taxes and enlisting local labour services, and a military draft system was created. Thus, the Saskya religious institution also took over the political administration system of Tibet at large. This was the first incidence of a politico-religious institution to arise in Tibet.

The Saskya period is said to be from 1240 to 1355 , but it had already started to decline by the early 14 th century. Saskya hegemony over Tibet was not really complete ; there were other comparably strong religious groups that could stand against them. Greatest among them was the Phagmo grupa. Although it was an active religious institution, during 14th century a politically minded member named Byang-chub rgyal mtsen (died 1373) established a political center, and conquered most of Tibet except for the Saskya's own country in 1358 . Thus, the Phagmo grupa had a combination of a religious head line and a political head line in the same family. Marking its peak from the 14th century to early 15 th century, the Phagmo grupa also declined over the course of time. Among the families under Phagmo grupa, a powerful one called Rinpung and successively another called Tsangpa khan gained ruling power over gTsan area centered in Shigatse. They had a close relation with the Karmapa sect, being hostile to the Gelugpa sect. Finally, those local political powers were expelled by Qoshot Mongol, Gushri Khan, who was on the side of the Gelugpa sect. He conquered all of Tibet and handed political power over Tibet to the 5th Dalai Lama in 1642. This was the first time for a Dalai Lama become the head of Tibet's combined 


\title{
Developmental Processes of Tibet Politico-Religious System
}

\author{
Chie NAKANE, M. J. A.
}

This essay examines the unique Tibetan characteristics of politico-religious amalgamation, engraved in her history. The acceptance of Buddhism by Tibet was well recorded in the middle of the 8th century, when the oldest temple Samye was built, inviting Indian pandits. By the beginning of the 9th century, Buddhism had become the state religion. However, the development of Buddhism in earnest commenced more than 100 years later after the assassination of the last king Landarma, who had suppressed Buddhism, in the year of 812 . With this event, the ancient dynasty, Tubo, fell and the following era of the second diffusion of Buddhism, called phyidar, began.

The first phase of the revival of Buddhism was carried out by the royal descendants of the Tubo kings, who established the royal residence in Western Tibet, Guge. Among them, king Yeshe Od sent youths to Kashimir to study Buddhism and, at the same time, was keen to invite pandits from India. It was in 1042 during Yeshe Od's grand son's time when the great pandit, Atisha, finally came to Tibet. By virtue of the active contributions of Rinchen bzangpo, who returned from India, and Atisha's great influence, Buddhistic activities were rapidly spread across Tibet, including Central Tibet (Dbus-gTsang), Kham and Amdo. Under the great monk scholars, several denominations were formed : and during the 11th and 12th centuries, famous monasteries were built by the founders of respective sects. For examples, in 1040 the monastery Zha lu was built in gTsang; 1042 Tho gling in Gari; 1057 Rwa sgreng in Dbus ; 1073 Saskya in gTsang ; in 1121 Gampo in Dbus ; 1158 Thel in Dbus ; and 1189 mTshurphu in Dbus.

Over the course of time, these monasteries became well established, developing scholasticly profound learning and producing a number of distinguished monk-scholars. Activities of the monasteries widened, grounded by firm economic bases. The basic form and structure of the monastic architecture in Tibet was also established in this period. The monasteries grew in stature and reputation. Not being disturbed by political affairs, unlike in later periods, religion prospered at its zenith. In retrospect, it was the golden age of Tibetan 